\title{
Maximising Impact Optimising Profit
}

by

Selin Gücüm \& Uygar Özesmi

Good4Trust.org

selin@good4trust.org - uygar@good4trust.org

\section{Table of Contents}

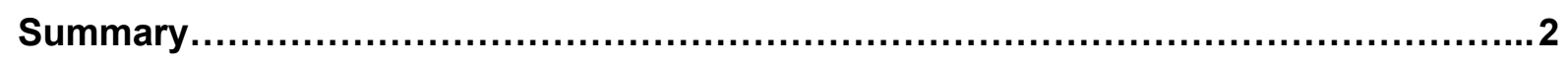

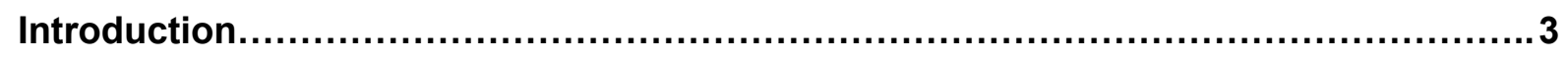

Historical evolution of the company and company law..................................

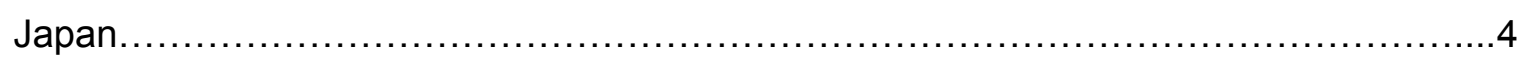

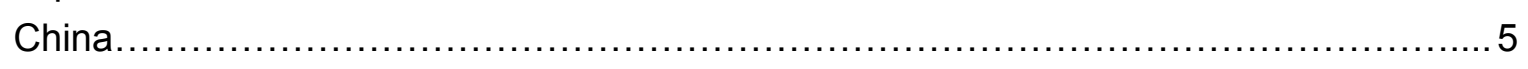

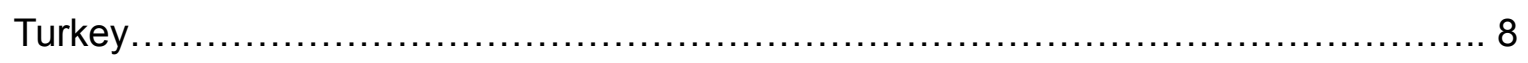

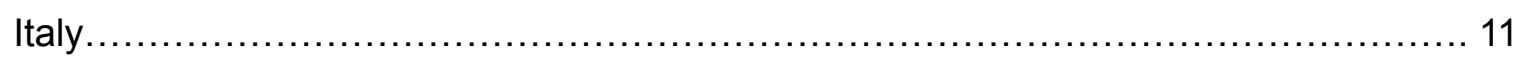

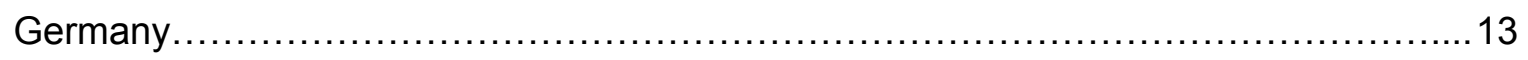

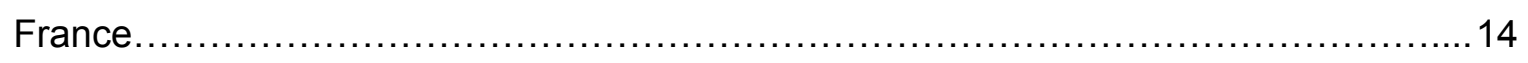

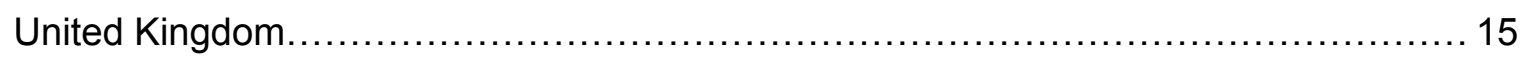

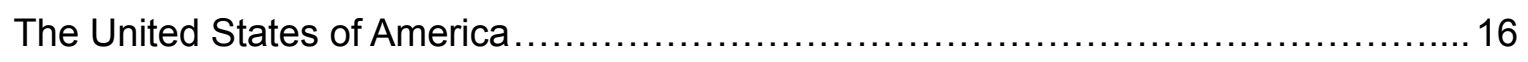

Chartered Colonial Companies........................................................

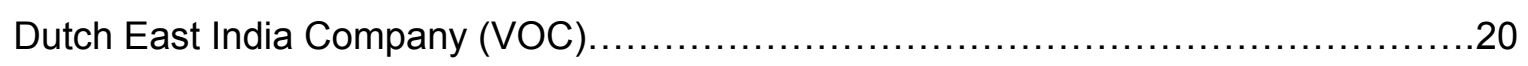

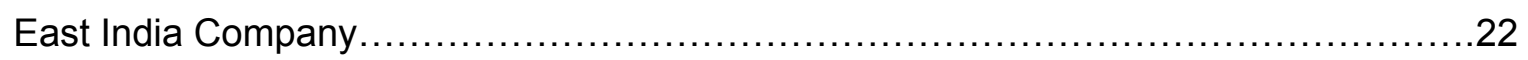

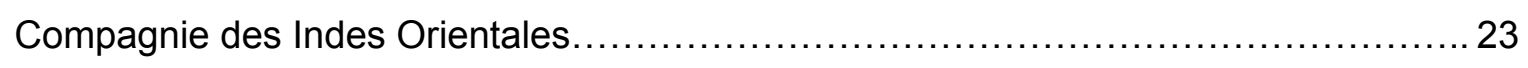

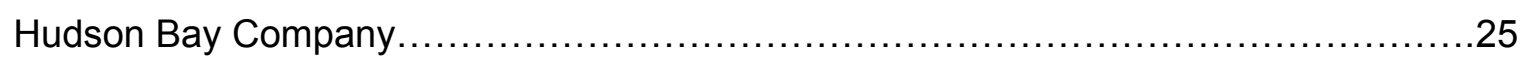

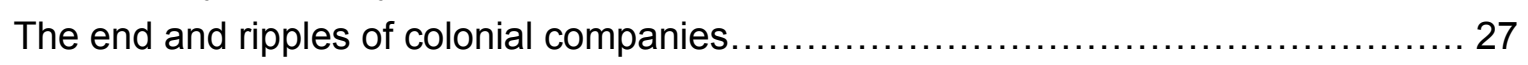

The Rise of Trusts followed by Anti-Trust Laws......................................... 28

Current Situation and Reform Efforts.................................................. 31

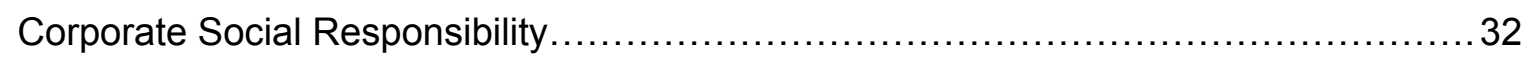

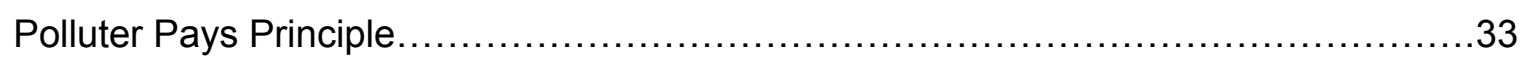

Value Based Approaches - Creating Stakeholder Value ............................. 34

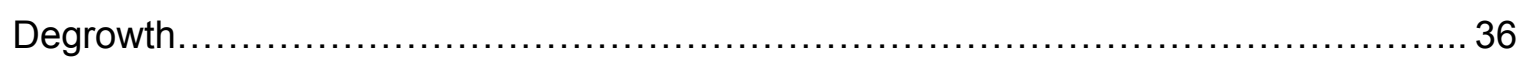

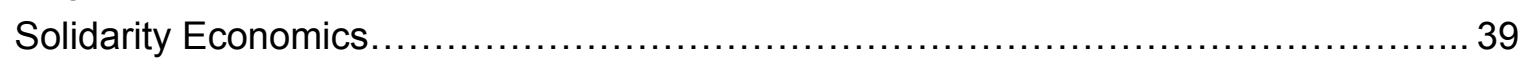

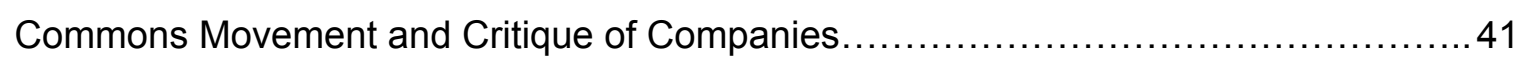


P2P - Peer to peer.

Social Enterprises.

Prosumer Economy

A new company law.

\section{Summary}

Humanity faces an imminent threat to its existence on this planet. The climate emergency and biodiversity crises are a direct result of our economic system. As the main instruments of our economic system, companies play a critical role in creating and solving this threat. Therefore, this book argues that if humanity is to exist on this planet, the economic system and companies, at its foundation, need to change. For this we propose an ecological and social purpose and impact driven company structure that uses profit to further the impact. A new law is needed and under this law all new and existing companies would need to structure themselves in this new way. If they cannot abide by this new law, then they will cease to exist by law, made by people, for people and this planet. This law would enable an economic system where companies instead of maximising their profits without regarding the environmental and social cost and damages, would maximize their impact, regenerating ecological and social resilience and integrity. Companies would not only have to "not harm the planet and people" but prove to be "benefitting the planet and the people" to exist and endure as an entity.

Historically companies were not built on the sole purpose to maximize profit, and it does not have to be the essential component. When we look at the historical evolution of the company and company law in different geographies, from East to West, from Japan, to China, Turkey, Italy, Germany, France, the UK and the USA, we see that they were first given the right to exist to benefit society. However the rise of the chartered companies set the stage for the company as the exploiter. We see this clearly in the Dutch East India Company (VOC), East India Company, Compagnie des Indes Orientales and Hudson's Bay Company. Unfortunately they are seen as the precursors of today's companies. Of course there have been counter measures to exploitation such as Anti-Trust Laws against Trusts being formed where and when chartered companies left the stage. Additionally, there were reform efforts against the "exploiting company" such as "Polluter Pays Principle", the value based approaches - "Creating Stakeholder Value", degrowth, solidarity economics, commons 
movement and the critique of companies, P2P - Peer to Peer, Social Enterprises and Prosumer Economy. However these reform efforts were not sufficient as we can see in the deepening of the climate emergency and biodiversity crises. Therefore a new company law is needed. As seen in our historical tour of company laws, almost all company laws in all nations have become extremely similar, therefore as an example we have amended the Turkish Company Code to reflect what we propose globally, a new company that maximises impact and optimises profit.

\section{Introduction}

The earth and living beings are threatened by the climate and biodiversity crises, both are directly linked to the modes of production and consumption, an economic system prioritizing profit maximization. The current economic model is unsustainable; alternative economic and development models are required. The global COVID-19 pandemic, by slowing down the economy and linked human activities, has slowed down greenhouse gas emissions and helped some biodiversity benefits as short term research indicates and offering potentially similar effects in the long-term (Corlett et al., 2020; Rutz et al., 2020; Pearson et al., 2020), as well as, the improvement in air and water quality (Zambrano-Monserrate et al., 2020). Various positive effects on the environment with the decline of "manufacturing and commercial exploitation of natural resources" (Bates et al. 2020) has clearly shown that the culprit is the way we organize our economy.

Moreover, social inequalities are rising and remain a challenge to be tackled. Income and wealth are increasingly condensed at the top. While the bottom 40 percent earned less than 25 percent of income in all 92 countries (United Nations, 2019), between 1990 and 2015 the portion of income going to the wealthiest 1 percent of the global population augmented in 46 out of 57 countries and areas from (United Nations, 2020). This increasing economic inequality is also valid within many countries, including emerging economies. Furthermore, climate change is also increasing this inequality by deepening poverty. Climate change is also at the base of intergenerational inequality (United Nations, 2020).

In order to propose effective and realistic solutions to the current state it is important to scrutinize the mechanisms of the economic system, the companies. In order to maximize profit, companies are lowering the price of the production as much as possible at the expense of the environment, nature, wages and social rights. Thus the pursuit of profit maximization in our imperfect market generates negative 
externalities which are not reflected into the prices in the market and not assumed or paid by the companies (Chakraborty et al. 2004; Bartolini and Bonatti, 2003).

Thus, we need a new company law which would endorse the optimization of profit instead of maximization. Therefore this article aims to examine the historical evolution of company laws in different countries and recommend an economically and socially just company law.

\section{Historical evolution of the company and company law}

The origins of the corporation or the company is highly debated in history (Harris, 2018: 89), however let us look not into the origins, but the development or rather evolution. It is essential to understand the evolution of companies and company law in history in different geographies and contexts, as understanding the past is the key to the future, we can then draw recommendations on what would be needed today.

\section{Japan}

Japan offers an interesting example as it hosts the oldest enduring company in the world. Kongo Gumi in Japan survived 1400 years (Hutcheson, 2007). However, despite a deep root in history, interestingly the first version of Japanese company-law, was developed in 1861 inspired by the German Handelsgesetzbuch (Nicholas, 2015). Nevertheless, it had very little impact on the actual governance of enterprises as the judges applied the law based on the interpretation of codes, instead of using precedents (Nicholas, 2015). Although the 1890 Commercial Code in Japan established the system of business organization as joint stock corporations, limited partnerships, and unlimited partnerships was also influenced by Germany, the later version of the Commercial Code in 1899 also contained elements inspired by French Commercial Code.

The 1861 commercial code marked an end of the pre-Meiji era, in which merchant houses ran by the prominent families and the guild system still survived (Nicholas, 2015). With the aim to industrialize, the easing of large-scale capital intensive enterprises was thought to be critical. Thus, Japanese policymakers advocated joint stock companies to achieve this aim of industrialization and progress. Large diverse business conglomerates called zaibatsu enterprises started as ordinary partnerships 
but evolved to be joint stock corporations. However, with the dense militarization of the Japanese economy in the 1930s have given rise to new zaibatsu, crucial for the heavy industry and war effort, at the expense of the family owned zaibatsu (Nicholas, 2015). As Frankl (1999) claims "New zaibatsu like Asano and Nissan exploited the joint stock form, performing more favorably in terms of profitability and sales growth than old zaibatsu firms such as Mitsui."

Whereas the new law was based on capital investment and profit maximisation for shareholder gain, the traditional Japanese companies like Kongo Gumi were based on values and guiding principles to achieve success in business and allowing it to surpass economic turmoils. These 16 principles are called Shokuke kokoroe no koto meaning "family knowledge of the trade." Such as "Listen to what the customer says," "Treat the customers with respect," "Submit the cheapest and most honest estimate," "Ensure long-term stability for employees," "Never fight with others," "Do not shame a person or boast" and "Communicate with respect" (Yoshimura and Sone, 2006). Among these principles "Submit the cheapest and most honest estimate" would contradict the main feature of most of the companies today that maximize profit. Which is in line with what Nugent and Werema (2015) proves, the lifetime of companies are limited with wrongful decisions which are often taken in the purpose of constant profit maximization.

\section{China}

In China "clan corporations," existed even before the introduction of European style Laws. These clan corporations were "relatively large commercial enterprises organized in the guise of the family" (Ruskola, 2018). Chinese society was oriented through Confucianism which morally prioritized the collective to the individual. As Ruskuola (2018) states, "for traditional Chinese law collective legal personality was a given". A relevant aspect of the orthodox Confucianism approach to the Chinese business enterprises was the anti-mercantile attitude and its general ideological opposition to profit-seeking (Ruskola, 2018). Under the paradigm set by the Confucianism family business and few state-controlled monopolies were the main form of business institution until the late $19^{\text {th }}$ century. In fact, family businesses have an extensive tradition in China and were considerable in scale and financially successful even on interregional markets (Goetzmann and Koll, 2005). Nevertheless, the largest and most successful of these enterprises (with few exceptions) relied on state support in exchange for a donation to public and imperial contracts.

Foreign-registered corporations were highly present in Shanghai in the 1860's. The Shanghai Stock Exchange allowed the entrance of domestic and foreign investment 
in China for the next 70 years. In 1872 the China Merchants' Steam Navigation Company, as China's first modern and joint stock company, reformed Chinese business practices radically (Lai, 1992; Goetzmann and Koll, 2005).

In the $20^{\text {th }}$ century the lack of a regulation such as a law of limited liability and the law of bankruptcy, became a hindrance to the expansion of those unlimited liability shareholding companies. With the ambition to compete with the West the 1904 Company Law was enforced as the first company law of China. Inspired by the Japanese and English company laws, it was envisioned to define Chinese corporate enterprise and assure the legal environment encouraging private investment in the aim of national prosperity. This was a brutal rupture from the former Chinese business environment in terms of finance and management dominated by kinship networks and state patronage (Goetzmann and Koll, 2005). The code encompassed features of the modern formula for privatization as requirements for transparency, separation of ownership and control, annual auditing and reporting requirements as well as the establishment of limited liability legally and excluding the direct participation of the government in the corporate entity.

The proclamation of the Republic of China (1912-1949) led the promulgations of several company laws. The 1914 Company Ordinance (Gongsi Tiaoli) despite having a minor effect on the structure of Chinese enterprises like its predecessor, it was a clearer law and acted as the basis of future revisions of the law (Kirby, 1995). Later in 1929 a new Company Law was promulgated by the Nationalist Government of the Republic of China (1925-1948), which had more effective control over the country (Wang, 2008). This law had an ambition to endorse state control of the economy and all private enterprises as well as "restricting private capital" (jiezhi ziben) (Kirby, 1995; Wang, 2008). However, this restrictive law and the eradication of extraterritoriality advantages disturbed the foreign corporations. Thus, in 1946 a compromise was reached between the Chinese government, interested in developing state capitalism, and foreign corporations, requesting for a liberal company code. Therefore, the law of 1946 contained an addition of a section for "foreign corporations" for the first time in China's corporate law history. During the communist regime of the People's Republic of China (1949 - today) a series of new regulations were initiated since 1950 in order to nationalize and collectivize the economy. Consequently, the nationalized companies lost their independence and corporate nature, by becoming either state or collectively owned entities (Wang, 2008).

In 1979 under Deng Xiaoping drastic economic reforms were made aiming to promote economic growth and attract foreign investment. In line with this aim, the Sino-foreign joint venture law adopted in 1979 allowed the creation of foreign-invested limited liability companies in China. On the domestic façade, local 
administrations intended to reorganize laws to reorganize traditional enterprises into modern corporations. Shenzhen, founded in 1980, reflects these aspirations as one of the Special Economic Zones endeavoring "capitalist policies on socialist soil". In 1986 , it was also the first local government to ratify regulations for a corporatization experiment. Also, in 1986, the National People's Congress established the General Principle of Civil Law which aside of serving as a "civil code" it also introduced new conditions for launching "enterprises with legal personality that possess property and are able to bear civil liability independently". Nevertheless, this former was succeeded by the contentious "Law on Industrial Enterprises owned by the Whole People" in 1988. This "1988 Enterprise Law" forged all state-owned enterprises "legal persons with civil responsibility for the property left by the state to their management and with independent budgets" but only remained in theory and limited liability persisted into the Chinese legal system (Wang, 2008).

It is only in 1993 that a nationally unified, effective and comprehensive company law was promulgated. As the first article stipulate it targets "to meet the needs of establishing a modern enterprise system, to standardize the organization and activities of companies, to protect the legitimate rights and interests of companies, shareholders and creditors, to maintain the socio-economic order and to promote the development of the socialist market economy" (Wang, 2008). In line with this, Wang (2008) suggests that the 1993 Company Law combines the systems of the two "standard opinions [...] stipulates two types of companies, prescribes their corporate finance and corporate governance structures". The revision of 2005 almost completely rewrote the 1993 Company Law and diminished various restrictions on business incorporation and operation in China.

As we can see above, the Chinese population was highly driven by the belief system of Confucianism until the 19th century. Guided by the "Golden rule" of "Do not do unto others what you would not want others to do unto you!" (Tu, 2013), Confucianism does not strictly oppose the notion of profit. According to Romar (2002) Confucianism allows to place a proper emphasis on profit through its ethical implications. This philosophy demands a moral level which considers the impact of one's behavior both on individuals and others. Therefore, Confucianism shows us that profit and ethics are not excluding notions but projects a perspective of a community and organization with more than a single aim of profit (Romar, 2002). Aftermath of the Opium Wars (1839-42 and 1856-60), the de facto colonization of China and gradual rejection of Confucianism for a "modern" European system. During the nationalist and communist regime these Confucian principles were entirely abandoned and even banned. However, China ended up replicating the same western style corporation under strong state policies. Under this highly 
concentrated version of the company system, with the aim of profit maximization, China climbed on top among the most polluting countries with low labour standards.

\section{Turkey}

In order to understand the foundation of the contemporary company in Turkey, it is pertinent to get an understanding of the Ahi Community structure as well as the Guild Organization (first called Lonca and then evolved to Gedik Teşkilatı). Ahi Community was initially a religious and social structure that emerged in the 13th century Anatolia and continued as a craftsman and artisan organization until the 18th century (Çağatay, 1989; Kazıcı, 1988). During the Seljuk Empire, the Ahi Community developed different functions and executed societal, cultural, educational, religious as well as administrational, political, military and economic activities in order to satisfy the necessities and needs of the time (Yüksel and Göksel, 2020). During the Ottoman Empire, it persisted and became an association and representative organization for craftsmen and artisans through its customs, traditions and principles (Küçükdağ, 2016; Ortaylı, 2010). Research indicates that this sociological formation adopted a peculiar cluster model. It regulated the relationship between the government and craftsmen and artisans concerning prices, quality, quantity and diversity of the products (Yüksel and Göksel, 2020). Some authors claim that the Ahi's essential task was the product and quality control as well as the price fixation (Odabaşı, 2008). Also, Şimşek (2002) states that in the Ahi organizations, the production that contradicts with craftsman manners and ethics as well as seeking excessive profit was not acceptable. The narh system was in place as a tool of price regulation in the Ottoman economy. Although, narh system could be found in different places since the Middle Ages, it had a significant place in the Ottoman Empire (Köktaş, 2016). It was an important tool of economic intervention for the Ottoman State, preventing stockage, artificial, excessive and unjust pricing and therefore excessive profit. As a state apparatus it would fix the level of prices for some products and prohibit selling above it (Köktaş, 2016). Pamuk (1990) adds on his definition also the fixation of standard quality. The system was highly valued by the authorities and applied strictly, especially during periods of crisis, depression and scarcity. Those who don't comply with it were stopped and punished (Köktaş, 2016). The system assured a balance between protecting and supervising the rights of the people while also protecting the rights and interest of artisans and craftsmen (Öztürk, 1991).

Köktaş (2016) suggests that contrary to the mercantilist policy of Europe in the $17^{\text {th }}$ century, the Ottoman Empire implemented economic policies oriented in promoting abundance of products within the empire and its interference in this direction to ease the access to products. 
In fact, Akbaş et al., (2018) claims that the Ahi were recognized as a civic organization through its purpose to create social benefits, founded by artisans and craftsmen and influencing directly the society's economic life. The Guilds (first Lonca and then later Gedik) might be considered as the continuation of the Ahi. Guilds also allowed regulations to fix the labor standard and the price, to be respected by the craftsman (Cohen, 2001: 191). Nevertheless, the Guilds had larger economic size and broader social inclusion. Hence, the Ottoman Empire had a peculiar economy, a combination of statist policy, high level of state intervention and private enterprise. Nevertheless, the capital accumulation/stock remained an unknown notion to the economy, because policies of the time aimed to prevent any strong accumulation of capital in one faction of society (Akbaş et al., 2018). The Ottoman Empire's economic view is based on solidarity and cooperation rather than conflict and competition. Therefore, concerning the matter of price and wage, the aim was to avoid competition (Çiftçi, 2004). In line with these, the producers organized in guilds were based on cooperation and solidarity indicating that the level of individualism within the craftsmen union was low, while the level of collectivism was higher. To the extent that, in order to protect the Guilds and the local products from the competition, the Ottoman administration has forbidden the importation of certain products (YazıcI, 1996:162).

Vakifs, as a pious trust with the objective to fund public goods such as fountains, mosques, roads or schools. "Across time and space, vakıfs have fulfilled a variety of economic, political, and social roles connected to religious salvation, poverty alleviation, urbanization, colonization, and new rulers' consolidation of power" (Zencirci, 2015).

However, authors Timur Kuran $(2001,2005,2011)$ and Gizem Zencirci (2015) argue that vakıf had another objective besides charity. Vakıf was used by wealthy state officials as a tool to avoid confiscation (müsadere). Any government officials' wealth as punishment or upon their death would be confiscated by the state (Akyılmaz, 2008). Also other wealthy muslims used vakıf before their death to avoid the distribution of their fortune among numerous heirs and concentrate wealth. By appointing one family member vakıf owner and conceding large amounts of money and properties to that vakıf, a heir could have been favored. Zencirci (2015) describes vakıf as a hybrid institutional form that overlapped "the divide between private property and public good, vakif did not fit into the Eurocentric vision of modern capitalism". Currently, vakif is a recognized institution by the Turkish Laws and is inspected by the Directorate General of Foundation (Vakıflar Genel Müdürlüğü).

In terms of the commercial law during the Ottoman empire, that was under the scope of the religious establishment, the clerical class, which had the legitimizing power. 
This avoided the formation of an influential economic elite (Balla and Johnson 2009). Moreover, this link between the Islamic laws and commercial laws also disabled the transactions including interests, therefore no class of money-lenders or bank institutions existed in the Ottoman Empire until 1856 which the first successful bank established in the Empire, and even this bank was supported financially primarily by the British and French (Balla and Johnson 2009). To Kuran (2005, 2011), this was due to the Islamic inheritance law and the Islamic partnership law uttering that death of one of the partners within the partnership would lead to the dissolvement of the latter. Despite the fact that the partnership could be instantly reconstructed by the partner's successors, as the laws order the split inheritances among numerous heirs this would create a rather large partnership considered as risky. Therefore, as Kuran $(2005,2011)$ states this situation prevented merchants or financiers to establish partnerships with many members, as well as to found long-lasting partnerships within a family.

While since the Medieval times, European partnerships developed to become larger and more complex to transform from basic partnerships (commenda) into family firms, joint-stock companies, and ultimately corporations, this was not the case of the Ottoman Empire in which partnerships mainly persisted simple until the nineteenth century (Balla and Johnson 2009).

Şirket-i Hayriye established in 1851 was the first share company of the Ottoman Empire and marked the economic and social structures of Ottoman life (Şensoy, 2018). As a maritime public transportation company it connected Bosphorus and Istanbul to each other for the first time. The company was established with the permission of the Sultan Abdülmecid in the official and declared purpose of adducing the western share company model conceived as an element of progress and wealth as well as to facilitate the circulation of those living along Bosporus toward the city. It was the first company to implement double entry bookkeeping records. The same year, 1851, when Şirket-i Hayriye was established, the first company law of the Ottoman empire Ticaret Kanunnamesi was adopted and a legal structure for the company was also schemed. In fact, this company law is the first law within the domain of private law in the Ottoman Empire. Notions as Limited liability between partners of the company and passage to double entry bookkeeping were introduced. The latter was executed in practice during the 1870s (Şensoy, 2018). The objective of the law was to regulate the trade within the western framework and to correct the deficiencies in the sphere of the trade law. The lifespan of a company became independent from the shareholders (Kuran, 2010, s. 53). Ticaret Kanunnamesi was influenced by the 1807 French Code de Commerce, to the point where some sections were exactly translated. Two hundred students were sent to France by the Ottoman government in order to assure this transition to the for profit business administration (Sensoy, 2018). 
With the establishment of the Republic of Turkey, a western-style Company Code was adopted in 1926 influenced by the European company laws (Eroğlu, 2008). Companies are currently regulated under the Commercial Code of 1957 derived from Switzerland "whose liberal principles of company law were followed". Nevertheless, it was not revised or amended significantly in fifty years, until the early 2000s when harmonization with European legislation started. In 2012, a new Turkish Commercial Code was promulgated (Needles Jr et al. 2012).

The notion of public benefit and ethics based production system such as the Ahi as well as social organisation for welfare and public good such as the vakıf was the fabric of Anatolian commercial enterprises till the end of the 19th century. They functioned well to create lively cities and a vibrant economy. The influx of modern ideas and ideals have integrated society with globalisation and hence created the same dynamic of public and natural exploitation.

\section{Italy}

Some say that the corporation is an invention of Roman jurists (Duff, 1938). According to Malmendier (2009), the oldest precursor of the modern corporation was the societas publicanorum, a society of government leaseholders/renters, that emerged in the 5th century BC. Additionally, Harris (2018) considers another institution of the Roman era, the peculium, to be a form of corporation as it produced a "de facto depersonalization by making a non-legal person the fulcrum of the business: the slave". Thus, it presented all the hallmark features in the functioning of the modern corporates, as asset partitioning (Abatino et al., 2011). However, these institutions were not written into the corpus juris civilis, and later disappeared until the Middle Ages.

The corporate form then revived in the 11th to 13th century by Roman law scholarship when new universities emerged. This was due to a need as city-based associations such as municipalities, universities, colleges, and guilds were forming. A new association was needed because they had to own property, set governance structures, resolve disputes, and so on (Avi-Yonah 2005). Roman law doctrines and institutions were not only the new reality of towns and guilds, but also spilled over to medieval canon law. The Roman Catholic Church used corporate laws to resolve its organizational challenges and provide legitimacy as a centralized and hierarchical body from the papacy to the monastery, fraternity, and religious order. 
While viewing the development of corporation and company law, it is noteworthy to mention the commenda, which emerged in Medieval Italy and as a general trend in the Mediterranean region (González de Lara, 2018). Although some might consider commenda as a "profit-sharing agreement or an equity investment, some as a partnership of labour and capital". González de Lara (2018) defines the commenda as a "real contract whereby a travelling merchant acknowledged to have received from an investor a certain amount of cash or merchandise, with which he ought to go on a voyage to do business, and obliged himself to share the profit which the Lord would grant with the investor, who nonetheless bore liability for any loss incurred while on voyage, either in the normal course of trading or from an act of God or hostile men, in proportion to his capital investment." This legal contract, commenda could be considered as a preliminary form of limited liability also providing the necessary "liquidity for attracting investments from the broader public".

Another medieval Italian partnership, the compagnia was derived from the Greco-Roman societas and formed a modern partnership. The compagnia, similarity to societas, was a consensual agreement by which two or more partners united their capital and labor for a shared objective or exploitation, then shared the profits and risks. Nevertheless, as González de Lara (2018) points out, the compagnia "had a separate fund distinct from the individual partner's own liable assets and operated under a joint name, as a firm, by which it conducted business" (González de Lara, 2018). In this line when contracting with third parties, partners operated on the account of the partnership and these developed in solidarity liability toward creditors for debts and obligations (Hansmann et al. 2006; Weber 2003).

In the modern period, the corporate laws were significantly influenced by the French Commercial Code of 1807, due to the Napoleonic domination of the Italian Kingdom. The first notable corporate law was promulgated 1865 and permitted the legal incorporation of joint-stock companies, società anonime (Aganin and Volpin, 2005). However, the first company law of the united Italy was the Commercial Code of 1882 which had more structured provisions for companies limited by shares and also allowed an easier incorporation. Due to the trailing state of the Italian industrialization process in the late 19th Century (Gerschenkron, 1962) universal banks flourished. Commerciale Italiana and Credito Italiano both founded in 1894 and supported by the German capital and administration are typical examples. From 1896 to World War I, Italy was marked by deep industrialization (Aganin and Volpin, 2005).

The 1942 Civil Code was an important regulation for the Italian company law and "improved shareholder protection in limited-liability companies" (Aganin and Volpin, 2005). Though some amendments in the 1970 and in 1990 were made. The latter were mostly done under the aim of harmonization with the European Community on the domain of market and the ownership transparency. Hence, the first Italian 
antitrust law was enacted in 1991. Later, major reforms were made in 2004 redefining the features of cooperatives and of the two important forms of company, Limited Liability Companies/Limited Partnership By Shares (Società a responsabilità limitata, Srl) and joint stock companies (Società per azioni, SpA).

\section{Germany}

The corporation, according to Von-Gierke (1900), may go back to medieval Germanic tribal traditions, in which the communal way of living may have led to the formation of corporations. The claim that the Germanic way was of community, association, and fellowship lost support with the discrediting of German nationalism.

It might be inaccurate to talk about a "German Corporate Law" as the unification of German states under the German Empire led by chancellor Otto von Bismarck occurred in 1870. Although Germany was behind the leading countries of industrial revolution such as England, France, and Belgium in the early 18th century, southern German states are considered to be part of proto-industrialization (Mendels, 1972). In this context of proto-industrialization, the incredibly extensive code of 1794 , Allgemeines Landrecht für die Preußischen Staaten (ALR), was promulgated as an intent to modernize Prussia. Beside comprehending matters like the civil, family and feudal law it also extended to areas such as mercantile law, labour law, and company law (Kuhli, 2013). Nevertheless, the ALR did not specifically deliberate about the business corporations. In fact, the Business partnerships were binded by the broad category of 'permitted associations' (erlaubte Privatgesellschaften) which could be defined as "voluntary associations for some private end." However, an ambiguous and broad concept of "common good" was the legal basis for all associations, essentially, companies could only be formed if they served the common good (Guinnane, 2018). Unfortunately, this common good approach was not explicitly carried forward to the Allgemeines Deutsche Handelsgesetzbuch (ADHGB) which was the legal framework promulgated in 1861. With the influence of French Revolution, Germany passed important structural and institutional reforms and, with the railroad revolution in the 1840s, significant economic development and rapid industrialization occured in Prussia. Thus, the adoption of ADHGB served the need to uniformize German states' commercial law and adjust the rules for company form by devoting a section focused on devoted a section to joint stock companies.

Although the German Commercial Code was mostly influenced by the french commercial code, it has a singularity in the domain of company law (Guinnane, 2018) in 1892 Gesellschaft mit beschränkter Haftung (GmbH, company with limited liability) was established as a new uniform legal structure for business enterprises in 
Germany. The 1892 law attaches to the main idea forwarded through bG (beschränkter Gesellschaft) which permits the new enterprise form to amalgamate features of the partnership with features of the corporation. By the end of the 19th century and beginning of the 20th century Germany became an important manufacturer especially in the domain of steel, ahead of Britain and France, and also coal (Kennedy, 1988: 200; 210-211). According to Feldman and Nocken (1975), despite being industrialized later than other Western European countries, Germany "developed a comprehensive trade association movement" before any other nations. $\mathrm{He}$ explains this with the strong corporatist mindset in the country and the interest groups deriving from corporatist tradition. From the 1930's GmbH became the main form of enterprise. As its name suggests, the $\mathrm{GmbH}$ attribute to companies is a legal person in which all owners have limited liability.

It is unfortunate that the requirement of common good, benefit, and positive impact to society has disappeared in the German Company Law as it focused on industrialization and limited liability.

\section{France}

The first known forms of corporations were wheat mills held and operated by companies in the 12th century by companies which had transferable shares. However, legally, the corporate form was first seen in local laws and ordinances in France. With Genoan and Florentine trade developing, the "société de commande" or "en commandite" started appearing in Marseille and Montpellier in the 13th century, and in The Ordinance of Louis X in 1315. With the contributions of Colbert, the royal Ordinance entitled "Pour le Commerce" was promulgated in 1673 as a commercial law. This law also concerned itself with the subject of "de la société" by distinguishing them into two types: société général and société commandite. Despite not defining these two in the law, the context indicates that "société général was a form of organization for collective trading corresponding very closely to the ordinary or unlimited partnership, and that the "société en commandite" was a form corresponding very closely to the special or limited partnership" Howard (1932). Thus, he claims that the 1673 Ordinance delivered a "codified partnership law for the French business community," and the limited liability of commanditaire members was clearly established. "Members en commandite (said Article VII of the Ordinance) shall not be liable except up to the amount of their investment." It was then clearly written into the Commercial Code of 1807. It explicitly talks about three types: the societe en nom collectif (ordinary, unlimited partnership), the societe en commandite (limited partnership), and the societe anonyme (business corporation). This 
happened despite the fact that royal chartered companies founded during the 1770's and 1780's had caused speculation and collapse hence Joint-stock companies met official disapproval during the Revolution and were then outlawed, however made a come-back despite bitter experiences. Still today the judicial framework for business organization is based on the law of 1807 during the Napoleonic period (Freedeman, 1965). However, free incorporation only came in the 1860's, forced by trade with neighbouring countries. In 1867 the "anonyme" was liberated from government authorisation. Although this sounds progressive, one should note that a corporation's purpose was conceived as essential in the company law of 1807, however this triggered heated debate and was deleted in 1867 law in the name of freedom of association (Segrestin et al., 2020). Only a hundred years later in 1966 the French company law was revised to update governance mechanisms and introduced the "Societe à Responsabilite Limitée."

As societal demand for responsible and mission driven corporations is on the rise, finally in 2019 a new law was promulgated. A new type of corporate form, the "société à mission" was introduced. This corporate form had 3 elements i) an obligation to consider the social and environmental implications of the business; (ii) an option for any company to define its raison d'être; and (iii),' for companies that adopt social or environmental goals by writing them into the company's by-laws and by setting up an ad hoc committee to monitor them. (Segrestin et al, 2020)

\section{United Kingdom}

The early development of corporations is traced back to the Middle Ages through the act of a group of people in common interest as a corporate body with a legal personality (Turner, 2018). The legal personality of a corporation in this context refers to the distinction between individuals who form the corporation and the "corporate as a legal fiction". In England the ancient boroughs were given incorporation charters accorded by the Crown (especially King John) as: "the right to sue and be sued; the right of perpetual existence; the right to own land; and the right to use a common seal, which verified that those entering a contract with third parties were authorised to act on behalf of the corporate body" (Cooke, 1950: 21; Turner, 2018). In this sense, the early forms of corporate bodies were the local governments of boroughs conceded by the Crown until the 17th century (Turner, 2018). The study executed by Angelucci et al. (2020: 37 ) indicates that borough served a public good by being a force against the trend towards absolutism, strengthened Parliament and restricted the power of the Crown. In the 16th century mercantilist corporates, holding the monopoly of trading rights attributed by the Crown, emerged in England. Two organizational forms characterized these corporations, the public joint-stock 
companies and regulated companies which diverged slightly. The regulated companies did not have transferable joint stock, the members of the company traded on their own account (Turner, 2018). With regard to limited liability, the members of the regulated companies did not own it, and the members of joint-stock corporations "did not derive this privilege from incorporation in and of itself - it existed only if expressly stated in the company charter" (Turner, 2018). Nevertheless, both forms of corporations had several features of a separate legal personality as well as hierarchical managerial structure. Also regulated companies detained the nearby monopolies whereas the joint-stock mercantilist corporations had the long-distance monopolies. The foundation of companies seen as separate entities from the government today, were then instituted and controlled by the crown (Woodward, 1985).

In the 17th century with the accorded monopoly trading rights around 40 companies were founded with nearly 10,000 total membership (Harris 2000: 45). Nonetheless, until the Glorious Revolution of 1688 , some business corporations were abolished mostly due to the abuse of the monopoly trading privileges by the Crown. As a reaction to this arbitrary and uncertain environment caused by the Crown, the Parliament promulgated in 1623 the Statute of Monopolies to reduce the ability of the Crown to sell new monopolies (Turner, 2018). The Glorious Revolution of 1688 and the constitutional changes had also an impact on the corporation and capital markets, leading to what is referred to as the "financial revolution."

According to Turner (2018) "the evolution of company law in England up to 1900 was all about the struggle to enable business enterprises to have all five of the core structural characteristics." It is conceived that five basic legal aspects characterize the modern company or corporation (separate legal personality, limited liability, transferable joint stock, delegated management, and investor ownership) (Kraakman et al., 2004). Yet it is to be seen what new characteristics will emerge now. Unfortunately the evolution of corporate law after 1900, was chiefly concerned with resolving the agency problems which arose out of conflicts created by the coming together of these characteristics, i.e., shareholders vs. managers, shareholders vs. shareholders and shareholders vs. other constituents (e.g., creditors and employees). However as we progress in the 21 st century the main struggle will be whether new legal formulations will emerge to resolve the conflict with interests of the public and the planet.

\section{The United States of America}


It would be heavily eurocentric to look at the evolution of companies in the United States, if we were not to look first at the approaches taken by the Native Americans. It is important to note that only the Olmecs, Mayas and Zapotecs have developed writing in Mesoamerica so most of the evidence is derived from European accountings, archeological and anthropological research (Cicarelli, 2012). Prior to the European arrival, also characterized as pre-equestrian era, Native Americans treated land as a common resource (Isakson and Sproles, 2008). As a matter of fact pre-Columbian, Native American tribes traded personal property, but never land (Nies, 1996). Also, Cicarelli (2012: 15-16) highlights that despite having an established system of taxation, the pre-Columbian, Native American did not establish the concept of private ownership of land. Isakson and Sproles, (2008) notes that Anderson and LaCombe claim that the property rights, tools and plants follow the "work-use-ownership" principle, "if you did the work to acquire a thing and used it productively, it belonged to you". Moreover, during activities requiring cooperative efforts, such as collective hunting, the harvests were allocated according to their labor in the hunt, although sometimes the leaders of the hunt or the owner of equipment used in the hunt got a larger share. However, Cicarelli reports that, in terms of sharing the fruit of their work Native Americans adopted the Golden rule of Treating others as they would like to be treated. Although many types of distribution were present in those societies, this ethic applied "to the basic wants and needs all people share and not to personal idiosyncrasies or deviant behavior" (Cicarelli, 2012). Nevertheless, the use of a primitive money, Wampum, was also common in the Native Americans economic system. All these show that the structure and understanding of the Native American before the arrival of Europeans did not lead to the emergence of a company configuration, but the Native Americans were wise enough not to exploit their common resources. Their economic structure was based on commons and the collective management of those commons hence there was no need for privatisation and companies. Their organisational model is similar to what is being proposed nowadays by the commons movement in the 21 st century.

As North America was colonized by European powers, the dominant colonial power in the area, Britain, was the legal and commercial reference. In the early years, despite having various forms of structuration in companies, most of the corporations initiated their legal existence by charters, "authority of specific or special statutes", or by acts of corporations passed by the governments of the colonies or states (Wright, 2018).

Hansmann (1996) states that some of these were for-profit, and some and even a larger proportion were non-profit chartered corporations. However, as Wright (2018) puts it, in that era non-profit corporations were defined as corporations which "may produce profit in the sense of generating revenues greater than total expenditures". Nevertheless, Hansmann (1996: 17-18) states precisely that it was forbidden to 
distribute those to the people who control non-profit organizations, therefore a "nonprofit organization cannot have owners" (Hansmann, 1996: 17-18). An additional distinction among the non-profit or non-pecuniary corporations is between ecclesiastical (religious) and lay (secular), in which the latter is distinguished between the civil (municipal) and eleemosynary (charitable). Whereas, joint-stock and mutual were the two types of the for-profit corporations (Wright, 2018). In the 17th century, companies tended to detain controversial monopolies in the colonies. Fewer corporations existed compared to the post-revolution period. However, Wright states that not only colonial corporations were also poorer and more restrained, but most colonial corporations were non-profit as it was harder in political and legal terms to charter them rather than incorporating businesses. He identifies an evolution toward the corporate dominance form between 1790 and 1860 . While previously, the "anti-corporate, anti-monopoly, anti-big business angst was evident", the corporate form dominated many fields of US business before most of the developed capitalist countries. Scholars recognize that a large number of nonprofits existed in the US during the early and antebellum periods. According to Kaufman (2008), from 1780 to 1810 the number of new non-profit charters surpassed the business incorporations in thirteen states. This was even noticed by Alexis de Tocqueville (1835).

The early US non-profits were classified by Gunn (1988) as: associations (agricultural, manufacturing, medical, science, transportation); reform associations (abolition, alcohol, peace, poverty, prostitution); religious organizations (Bible, church, missionary, Sabbatarian, Sunday school); charitable and benevolent societies; fraternal orders; education associations (academies, colleges, libraries, and lyceums); volunteer service (fire, militia); and labor associations (protection societies, trade unions, worker cooperatives). The non-profit organizations did not necessarily receive or request charters "like unincorporated joint-stock companies, some nonprofits formed under articles of association and asserted corporate rights". However, there were also certain nonprofits founded under the general incorporation statutes as the ones passed in New York and New Jersey. Moreover, controversial non-profit corporations, like pawn shops, were either non-existent or the few established ones were not successful (Wright, 2018)

Although they may be numerous, yet a hostility was present toward the non-profits perceived as a threat to the power of state. As a reflection of this, the quantity of the property that a non-profit could detain was restricted in some states, and banned bequests (Brooke, 1989). This endured until the 1844 Supreme Court decision conveying federal government encouragement for the property rights of non-profits (Wright, 2018). Hall (1992) states that attempts to extend the legal privileges and scope of the private elementary institutions occurred only during the post-Civil War period. It is noteworthy to mention that non-profit leaders sought to achieve social 
status, and "soft power" rather than money. Another valorized element was connections with leading voluntary organizations, which were functioning as semi-public spaces meaning that different classes, occupations, political parties, religions, or regions could come together, interact, and collaborate (Wright, 2018; Doyle, 1977)

It is noteworthy to mention that even after the independence of the US and the establishment of the Constitution, a mistrust persisted toward the companies and companies were usually incorporated through a special act of the legislature (Wallis, 2005; Blumberg, 1993). Moreover, the previous state corporation laws tended to have been restrictive in form, under the aim of hindering the strengthening of corporations in terms of wealth and power (Smiddy and Cunningham, 2010). In 1811, New York became the first state to enact a corporate statute through "The Act Relative to Incorporations for Manufacturing Purposes of 1811". This law allowed free incorporation with limited liability, as well as enforced a simple and public procedure in order to initiate corporations instead of seeking an exclusive permission by the legislature. However, this law only concerned the manufacturing businesses. This law was followed by the state of New Jersey in 1816, the by other states as Connecticut 1837 and Delaware in 1883. An important event for the evolution of the corporate law, was the declaration of the Supreme Court in 1819, by considering that the private corporate's charters can not be arbitrarily amended or abolished by the state governments and therefore are judicially "inviolable" (Campbell, 1975).

Although State laws rule the technical aspects of corporations, the federal laws are applicable to them. For instance the 1933 Security act, the 1934 Security Exchange Act along with the Sarbanes-Oxley Act of 2002, are some of the federal laws which corporations must comply with. Other federal regulations are applicable regarding employment, environmental protection, food and drug regulation, intellectual property and other areas.

It can be seen that the non-profit companies were the dominant form in the US for a long period. There was huge mistrust against for-profit companies, values of social organization, solidarity and public benefit were predominant in US society. This social paradigm where soft power of social status by doing good and charity was in high esteem progressively changed and was replaced by status acquired through money and profit, and finally the rise of limited liability placed the cap stone.

\section{Chartered Colonial Companies}


The chartered companies of the 16th-17th century were companies such as Dutch East India Company (VOC), British East India Company (EIC), Compagnie des Indes Orientales $(\mathrm{ClO})$. Along with these companies and even little earlier, other important chartered companies existed as the Muscovy Company known as the Russia Company (1555-1917) and the Levant Company also referred to as the Turkey Company (1581-1825). The latter was a "merger" of Venice Company and the Turkey Company gathered in the Levant Company (Devecka, 2015) and mainly traded with the Ottoman Empire along with the Levant and other Mediterranean countries. While presenting diplomatic and political interests for both (Wood, 1935; Devecka, 2015). The Muscovy company, the first English joint-jock company (Pettigrew and Smith, 2017), once contemplated annexing or turning North Russia into a colony (Dunning, 1989; Lubimenko, 1933) but eventually failed. However, as much as both have an interesting history and evolution, they never became a company-state or a colony (Devecka, 2015). Thus, they do not force the level of atrocity that other chartered colonial companies reached in the pursuit of profit-maximization.

Chartered company is a corporate status granted with a charter from the sovereign authority of the state defining specific rights. Multiplied dramatically in the second half of the 16th century in Europe, these chartered companies are often characterized by monopolistic trading rights on a precise geographic area and occasionally a specific type of trading goods.

Hudson Bay Company and other stated monopolistic companies are the foundation of modern multinationals. It is important to note that these are prototypes of the modern business corporation with limited liability of the investors as an important innovation (Ventoruzzo and Sandrelli, 2016). Here we will exemplify 4 of these to show how this foundation is rooted deeply in colonization and violence, that made millions suffer and the logic of exploitation ingrained in the notion of the company as we know it today.

\section{Dutch East India Company (VOC)}

Dutch East India Company (VOC, Vereenigde Oostindische Compagnie) was chartered in 1602 and lasted for two centuries. Along with the company's private aspect, the preamble of the charter also highlighted its profit-maximizing objective (Harris, 2018). It is considered a prototype of companies in modern history (Vliet 2014). 
The charter granted to VOC a twenty years of monopoly of all trade from the east of Cape of Good Hope to the west through the Strait of Magellan (Prakash, 1985). It also rendered state-like rights a feature typical of many chartered corporations (Brandon, 2017: 215). The VOC had the ability to wage war, imprison and execute convicts, negotiate treaties, strike its own coins, and establish colonies. The VOC was also the pioneer of foreign direct investment and especially the modern joint-stock companies by establishing the Amsterdam stock-exchange market. This system allowed the company to distribute the high risks related to this enterprise as piracy, disease, shipwreck, and particularly the interchange of inelastic demand and rather elastic supply of spices. Interestingly VOC also hosted the first recorded shareholder activism and short selling in history in 1609 by Isaac Lemaire due to a dispute of corporate governance.

Establishing a global trade network, the VOC was a significant element for the construction of modern economy and business principles for administration and management. Transported 2.5 million tons of Asian products back to Europe, four times more than its nearest competitor, the English East India Company. This also marked the beginning of consumerism (Shorto, 2013). Nevertheless, the company was also at the heart of many atrocities, violent and inhumane methods, including immensely large scale of slavery and exploitation and according to Shorto (2013) environmental destruction. He insists that "it shuffled the global ecosystem" intentionally and unintentionally through transportation of plants, animals, and insects across the planet. Furthermore VOC was essential for the expansion of Dutch colonies around the world, qualified as the merchant-driven form of colonization by Brandon (2017).

Slave labour was used by the Company functioning, as enslaved people were used for the reconstruction of conquered territories by the VOC, for fortification, loading and unloading the ships in the ports and for agriculture. As a general policy of VOC, slaves were imported to the occupied territory rather than the enslavement of the local population. For instance, thousands of slaves were shipped in South West Ceylon (current Sri Lanka), approximately 3,000 in November 1660, for labour (Raben, 1996:131). The slave numbers only in Colombo reached 1570 slaves in 1685 and 1741 slaves in 1697 (Knaap, 1981). Moreover, beside the Company owned slaves, privately owned slaves during the company rule have increased the number of slaves in South-Western Ceylon up to 10,000 by 1661 (Raben, 1996). Thus, almost $54 \%$ of the Dutch Colombo were formed by the slaves in 1694 (Raben, 1996:104). This also led to massive private illegal slave trade by the Company employees (Raben, 1996:131).

The VOC was dissolved in 1799 due to various factors. Many authors point out the growing corruption as the main reason behind the company's collapse (Kroef, 1948). 
Also, the increasing amount of the company's debts (Kroef, 1948), weakening major wars (the Fourth Anglo-Dutch War of 1780-1784 and the Franco-Dutch War of 1793-1795), internal political turmoils in Netherlands (the Orangist revolts of 1747-1748, the Patriot Revolution of 1785-1787 and the Batavian Revolution of $1795)$ and the huge financial problems that led to de facto nationalization of the VOC in 1795-1796 are also conceived to be among the reasons of VOC's dissolution (Brandon, 2017). Nevertheless, Brandon (2017) argues that the deficit of the "corporate sovereignty" model and structure is a changing conception of State sovereignty and economy based on free-trade ideology, which also contributed to this dissolution. After which the Netherlands was one of the first nations to implement a system of corporate governance (Muijsenbergh, 2002).

\section{East India Company}

The British East India Company (EIC) was also another chartered joint stock company and the main rival of Dutch East India Company (VOC). EIC received the Royal Charter in 1600 in a context in which the Portuguese and Dutch were already in India. In fact, beside the economic interests there was also political and nationalist will to excel in the maritime trade in order to outdo Spanish and Portuguese or even religious reasons (Lawson, 2014).

It shared the common characteristics of the other joint-stock companies as detaining a strict monopoly of trade with the specific geographic area and the mercantilist vision of the era considering the world as a zero-sum game in which exports should prevail on imports.

Although the imperialistic and state-like rights (claiming lands and colonies, to have a military, to wage war, to resolve peace and to enforce law) are frequent in those joint stock companies, EIC has a remarkable role in the expansion of the British empire in the Indies and further east. Lawson (2014) expresses this as a change in raison d'être from a company established for trade purposes to control and governance of territories. Barrow (2017) joins this idea by articulating that since the Anglo-Mughal War (1686-90) and during the eighteenth century EIC faced massive change "from being principally a global trader to becoming a state."

The established "corporate colonialism" of EIC in the Indies were marked by pillage, exploitation of the local population, violence, and famine (Dalrymple, 2019: 51; 132; 377-378 and 639). An example of this is the Bengal Famine where it is estimated that 10 million people, over a third of the Bengal population, died of hunger and 
disease from 1765 to 1773 due to EIC's economic policies (Damodaran, 2006). Also, the report of the famine commission indicates that from 1765 the British East India Company took the control of the diwani of Bengal to 1858, 12 famines and four severe scarcities occured in Bengal (Damodaran, 2006). According to Damodaran (2006) the most important factor in the severity of this famine was "the gradual erosion of a way of life and the whittling away of traditional means of subsistence that rural communities in Bengal went through in the eighteenth century, a process that was hastened under colonial rule". Dalrymple (2019) emphasizes that "Western imperialism and corporate capitalism were born at the same time" and he demonstrates the abuse of fatal power as well as the unaccountability of EIC rule in Bengal. All these atrocities committed by the EIC have contributed to its own end. On the 10th of May 1857 the resentment of the local population gave rise to a rebellion, the Indian Mutiny. The cause of the revolt is conceived as the forced westernization of Indian population in every area, and the harsh and unjust tax collection policy of EIC. However, the rebellion was crushed and people were murdered in the "bloodiest episode in the entire history of British colonialism" (Dalrymple, 2019). As a consequence, in August 1858 the EIC was formally dissolved and the lands and armies owned by the EIC passed to the British Crown.

\section{Compagnie des Indes Orientales}

Founded in 1664, Compagnie des Indes Orientales (CIO) was initiated as a fusion of three other French companies in the east (Compagnie de Chine, the Compagnie d'Orient and Compagnie de Madagascar) (Harris, 2018). It aimed to compete with the Dutch, English and Portuguese. When Jean-Baptiste Colbert's (1619-1683) came into power he was committed to improving the "establishment of commercial companies with greater privileges" (Dung, 2017). Despite the fact that $\mathrm{ClO}$ took East India Company and Dutch East India Company as the example during its foundation, it differs from them (Dung, 2017). First of all ClO was not a joint-stock corporation and was founded by the Crown with a significant influence of the latter at the expense of the shareholders (Conac, 2005). However, similarly a monopoly of trade from east of Cape of Good to the Straits Magellan with state-like power attributed by the Crown (Shakespeare, 1997).

The colonial intentions of $\mathrm{ClO}$ were clear from the beginning. For example François Martin (1634-1706) was both the Commissioner of $\mathrm{ClO}$ and the first Governor and founder of Pondicherry, the future capital of French India in 1674. According to Dung (2017) he played a major part in attaching the ClO with the authorities of these countries, and endorsing the ClO's involvement in Dai Viet in the 17th century. 
However, they were unable to separate limits between trade and religious propaganda in the East Indies, and failed to convert chiefdoms and their subjects to Catholicism (Dung, 2017). Dung (2017) also underlines the main purpose of the 17th century's European traders, which was "seeking profit". Nonetheless, with the change in political context of the 18th century, the british and french purpose derived rapidly into colonial conquest ${ }^{1}$ "transforming efficient and close trade relations into aggressive trade commitments." During the 18th century and especially under Joseph-François Dupleix, French undertook an aggressive policy toward both the Indians and the British. They also intervened directly in local politics to the extent of installing their preferred candidate on the throne when a local ruler died (Barrow, 2017).

Despite the various exploitations of $\mathrm{ClO}$ in India, most slavery and slave trade occured in the Bourbon Island (todays Reunion) and Madagascar (Thiébaut, 2017). However, it is also estimated that 25000 slaves were removed from Mozambique, the Portuguese colony, by the French under the COI (Capela, 1987). Moreover, Madagascar was performed due to profitable prices and absence of european intermediaries (Thiébaut, 2017). The COI had also the monopoly and stranglehold in the slave trade between Senegal and America in the 18th century until 1748-1750 in which it decided to cease and hand over this exclusive business right to the private ship owners, as the slave trade in Senegal became less profitable (Haudrère, 1989: 242 ). In short, from the end of 17 th century and during the 18th century the COI widely used slavery and especially the Indian Subcontinent served as a captive source toward Mascarenes as well as some captives from Pondicherry were also placed in Bourbon (Ève, 2010).

Despite the fact that slave trade was not at the heart of the CIO's business activities, it increased through time. Slaves were predominantly used for agricultural plantations rather than trade, especially in Bourbon, Île de France (current lle Maurice) and Madagascar for the agriculture of valuable and tropical plants such as coffee, sugar, and cotton. Slavery was perceived as a necessity for CIO's business as well as for the colons whether it was for agriculture, infrastructure constructions, or other activities. Hence, the number of slaves in Mascarene Islands expanded from 5031 in 1731 to 38479 , in 1767. The proportion of slaves reached up to $80 \%$ in Mascarene between 1770 and 1820. Similar trends were observable in other parts of Africa controlled by the $\mathrm{ClO}$, by the period of the French Revolution the number of slaves extended to 75178 in Ile de France and further grew to 107563 in 1809 according to some sources (Thiébaut, 2017). In fact, an important amount of slave

\footnotetext{
${ }^{1}$ It is important to express that trade undergoes a change to pursue trade benefits on the spot, a new method was executed. "Goods circulated from Indies to Indies, as East Asia and India became the ultimate target in trade colonialization and market monopoly." (Dung, 2017)
} 
trade occured within Africa especially to eastern part for agricultural purposes and to the island which allowed to the $\mathrm{ClO}$ sailor to stop and rest. It is estimated that during $\mathrm{ClO}$ period 300 slaves were shipped per year toward the east of Africa to Madagascar, between 1769 and 1810 this became 1000 slaves per year and after 1810 the number increased to 2000 slaves per year (Thiébaut, 2017; Larson, 2000).

The $\mathrm{CIO}$ had financial problems and was weakened by maritime wars starting in 1672, and eventually lost its monopoly in 1682, later formally dissolved in 1719 . In 1719 the banker John Law absorbed various french companies in different regions and combined them all under the name of Compagnie des Indes which also held a monopoly. However, due to the English "South Sea Bubble" in 1720 and the speculations with it, that company was already in bankruptcy in 1721 and reorganized in 1722 with new privileges given by the king in 1723. However, Compagnie des Indes declined after 1746 because of the spendthrift policies of the french government and the Seven Years Wars (1756-63). With the loss of the monopoly in 1769 and the transfer of all properties to the state in 1770 due to the bad financial situation, the company was officially dissolved in 1770 . The final Compagnie des Indes was founded in 1785 with a monopoly privilege, but after the French Revolution (1789), in 1790, the National Assembly took away its privileges and the company was finally totally dissolved in 1794 (Shakespeare, 1997).

\section{Hudson Bay Company}

Chartered and based in 1670 in England, Hudson Bay Company (HBC) was formed by french merchants. Also a typical example of "corporate colonialism" and joint stock company, the HBC did fur trade business in James and Hudson Bay and in $40 \%$ of what is today Canada (Badaracco, 2018). These areas were English colonies whereas the main portion of the surrounding territories were French colonies, New France. The same monopoly was run by the Company of New France as granted by the French Crown in 1627. HBC and CNF were motivated by the extraction of resources and expansion in order to maximise their profits of capitalist development (Comack, 2018). HBC was also a "company-state" holding sovereignty in Rupert's Land Territory of Canada (Cavanagh, 2011). Although Cavanagh (2011) states that company rule was never clearly cut, the exercise of jurisdiction progressively extended beyond HBC's subjects, indentured labourers, over the local population of the First Nations. Furthermore, HBC has made an effort to ensure that its own sovereignty was greater than any indigenous forms of sovereignty in Rupert's Land (Cavanagh, 2011). Thus, as Carroll and Sapinski (2018) expressed, HBC has committed "one of the biggest land grabs in history." While large scale extractive activities were conducted by corporations in 19th century like mining, forestry, oil, 
and gas on Indigenous lands "The free, informed and prior consent of Indigenous peoples was rarely obtained, nor was a consideration ever given to the actual costs of extractions, such as environmental damage, water contamination, air pollution and the destruction of plant, fish and animal habitat" (Palmater, 2017: 54). Various authors indicate that the Indigenous people were also an employee of the HBC; however, Judd (2008) provides a more nuanced and precise explanation over the position indigenous people within the HBC. 'Race' or ethnic origin influenced the hierarchical position within the company. Despite the fact that Indigenous were crucial to the fur trade as guides, interpreters, hunters, transporters, or canoe builders they were hired only seasonally or to accomplish a certain task under no contracts. This would prevent them from obtaining security and tie them to fixed annual salaries. The unification of the North West Company and the HBC in 1821 made the HBC's hierarchical system even more conservative toward the status of Indigenous people. They were viewed as a workforce however with low salary, they were used to perform burdensome tasks avoided by other groups, especially at Methye Portage. Thus, indigenous were at the lowest level in the company. Although this did not please them the lack of rewarding alternatives condemned them into what the fur-trade monopoly offered. Same prejudicial approach became prominent toward the increasing mixed blood employees in the 19th century. Toward this unjust system, lack of proper food, the danger of being icebound, and the constant hard labour desertions and mutinies on the transport lines became a common practice of protestation for indigenous and mixed-blood (Judd, 2008). Toward the end of the 19th century HBC faced difficulties to sustain this business due to the inability to renew its monopoly, the declining fur trade business which became less profitable (Throckmorton, 1958) and the transfer of Northwest territory and Rupert's land to the newly established Canada in 1870 was still profitable with $£ 300,000$ (more than 36 million in 2020) (Department of Justice, 2021). HBC opened its first department store in 1881 selling dry goods, groceries, and hardware. Nevertheless, in 1970's it enhanced trading and fur-collecting stores in northern Canada through large chains of department and discount stores. HBC was involved in petroleum and natural gas ventures in the 1920's as well as real estate and financial services. Due to financial problems in the 1980's HBC sold the gas and oil ventures. It was only in 1991 that HBC dropped out from the fur trade business but it remains as one of the largest companies in Canada despite its shady history. However the dark history continued with environmental atrocities and HBC was added to Canada's Environmental Offenders Registry due to its bad record on environmental irresponsibilities. The HBC was fined for the release of the chemicals, failing to alert the government immediately after the leak, as well as for failure to take all possible measures to prevent the incident, and failure to submit its annual reports for 2008, 2009, and 2010 on time. Despite knowing the harmful impacts on the health of aquatic ecosystems and the wildlife, released Polychlorinated biphenyls (PCBs) in May 2011 , which exceeded the legal limit by 146,000 times. In 2016, one of HBC's 
Montreal store violated the Canadian Environmental Protection Act releasing 146 kilograms of toxic industrial chemicals into the environment and was fined for it (McSheffrey, 2016).

\section{The end and ripples of colonial companies}

The historical review among these different countries and cultures indicates that companies did not always have the primary purpose to maximize their profit at all cost.

Corporates already existed previously and were important institutions in the $15^{\text {th }}$ and $16^{\text {th }}$ century in Europe. These corporate entities enabled cities to have a degree of independence from the political and divine authorities. Unlike the current corporates, Medieval corporates mostly did not seek profit maximization. Their main objectives were grounded on regulatory order, performing public or semi-public purposes (Harris, 2018). Also, these corporates were diverging in their nature and function from the current corporations. The Medieval corporates were established to organize the municipal governance and city-based economic activities, as well as educational activities extending to universities (Black, 2003; Epstein, 1998; Ogilvie, 2011; Harris, 2018). Harris (2018) called them "total institutions" rather than simple investment tools. Notably, Harris also points out that the modern corporates inherited from them the separation of legal identity from its members. This assured a lasting and stable legal personality, making corporates "potentially immortal". Indeed, the legal concept of corporate personality forge a key rearrangement. The corporation gained a distinct legal personality than the individual, the crown or the state. Although the concept itself originated from late Medieval Europe it "provided longevity, a device for asset pooling and the basic delegated governance structure".

Unfortunately, the second half of the $16^{\text {th }}$ century is a turning point in the evolution of a corporates as they progressively adopted a profit-oriented objective such as the regulated corporations, who embraced profit maximization as their main purpose (Scott, 1912; Harris, 2018). This change in the nature of organization entailed change in legal conception about corporates. While until $16^{\text {th }}$ century businesses and partnerships in Eurasia were structured likewise to small partnerships, family firms and ethnic networks, Western Europe took a diverging path by structuring in form of business corporations with joint-stock capital (Harris, 2020). Harris (2020) calls this a transformation from personal exchange, or cooperation (Those based on family, locality, or ethnic kinship ties) and Impersonal exchange or cooperation, (Those between strangers), thus he conceives the joint-stock corporations an organizational 
revolution (Harris, 2020; Harris, 2018). In this sense, colonial companies', as VOC and EIC, organizational schemes marked the first long-lasting joint-stock corporations established large-scale, multilateral, impersonal cooperation in human history (Harris, 2020). Furthermore, the study of colonial companies is worthwhile to evaluate the current situation as EIC and VOC were the precursors of the modern business corporation by conveying essential characteristics transmitted to today's business corporates. Harris (2020: 252) notes that among the seven core characteristics in his view, four were attributed for the first time in the $17^{\text {th }}$ century "as part of the design and early evolution of the first two joint-stock business corporations, the EIC and the VOC" while two already existed. So, according to him "joint-stock equity finance; lock-in of the investment; transferability of the interest (decision-making and profits) in the corporation; protection from expropriation by the ruler/state" were an innovation of these colonial joint-stock companies. In the institutional approach of Harris $(2018 ; 2020)$ the development of the joint-stock companies was a crucial juncture in the history of business organizations and stock markets, a huge institutional innovation to overcome "unaffordable environmental challenges".

Therefore, all these paths of evolution are crucial to shape a better understanding of companies of today, and what is needed tomorrow. The pioneers of our current company organization, were immensely powerful and focused to the aim of profit maximization to the extent of heavy exploitation and atrocity were not spared for this end. They resulted in debts of the exploited, unnecessary wars for more profit, local revolts and internal corruption. All these are an indication that our current inheritor system, also struggling, has no choice but to undergo massive and crucial change. A necessary and unavoidable change in the conception of its aims and purpose, minor modification that conceives the same problems will not do.

The colonial companies and their methods rippled in time, all the way to the end of the 19th century. These evolutions led to the rise of big company trusts seeking profit-maximizing through solidification of power and control of the market. In the 19th century US, the new concentrations of economic power exercised by big industry-dominating companies became a societal issue, as much as an economic one (Abbott, 2021). The unease about damaging business combinations echoed through cartelization and trust formation and the surging practices as discriminatory and predatory pricing (Abbott, 2021). These monopolies or near monopolies were referred to as "trusts" since that time.

\section{The Rise of Trusts followed by Anti-Trust Laws}


"Trust" in the corporate world, by definition, is a very large company or a combination of large companies that cooperate with each other towards a common interest. The trust holds most of the market share in that related sector and, as a result, controls the price in the market for the related goods/services. Trusts are usually perceived as having negative effects on the market where small companies are not given a chance to survive and where consumers are stuck with the price set by the trust.

Throughout history, antitrust laws and decisions of the courts changed depending on the political and economic conditions of the period. The first known monopoly laws come from Athenian city states, where in general, freedom of trade and competition was a rule. However, in the beginning of the sixth century legislator "Archon Solon, cancelled all mortgages on lands and all debts and he forbade debt slavery for the future. He devalued the Athenian currency in order to facilitate trade and he prohibited the export of grain." In Attica grain was a vital commodity for survival. Trade in grains and the allure of large profits gave rise to speculators who knew how to manipulate the market. "To protect the people from speculative conspiracies and combinations of the grain importers and grain dealers, all those engaged in the grain business were required to observe complex prohibitive laws and regulations." The penalty for violating the laws prohibiting grain monopoly was death (Kotsiris, 1988).

In Turkey, during the Ottoman period similarly prevention of cartel formation and artificial price-fixing and import tariffs were used to prevent monopolisation through the Narh system as mentioned previously. In England before anti-trust laws were put in place, the courts depended on common law in deciding on cases about market competition and would consider if there were any "restraints on trade," (Sawyer, 2019). The first known restrictive trade agreement under common law by the English Courts was Dyer's Case in 1414, where the person was restricted to do the trade for half a year. Then in 1624 the "Statute of Monopolies" was adopted to establish fairness in trade. Later in 1852 The Austrian Penal Code provided that "agreements... to raise the price of a commodity... to the disadvantage of the public" is punishable and void. Canada in 1889 promulgated the "Act of Prevention and Suppression of Combinations" which was the first competition-related legislation of modern times (Papadopoulos, 2010).

In the United States as businesses grew in size and interstate trading started, common law and state laws became insufficient in regulating interstate businesses (Sawyer 2019). In 1890, Sherman Antitrust Act was passed in the US Congress and federal regulations on monopolies were put in place for the first time (Sawyer, 2019). Long before the Sherman Act, US society as mentioned before had a deep hostility toward monopolies.First state constitutions, written in the 18th century, condemned monopolies as violations of the principles of equal rights and equality before the law. Founders, including Thomas Jefferson, wanted to include a prohibition on monopolies in the federal Bill of Rights. While The Sherman Act was effective in the 
battle against the multi-state cartels, it was less effective in preventing monopolies because it was only suspicious on contracts between companies, but it allowed for vertical and horizontal mergers and acquisitions in an industry (Sawyer, 2019).

Through the implementation of The Sherman Act, in 1911, the court has broken down Standard Oil Co. whose "market share suddenly rose during the 1870 s, from about 4 percent of the US petroleum industry to fully 90 percent, sparking the fears that gave birth to the antitrust movement," into 34 parts (Lamoreaux, 2019). The court decision was based on "rule of reason analysis". At the same time, the courts decided to dissolve American Tobacco into four competing firms as well as "Northern Securities Company" who controlled multiple railroad lines into lines managed independently (Sawyer, 2019).

In the 1970's, the view that government intervention should be minimal was dominant. According to the Chicago School of Antitrust Policy, markets were self-correcting and government interventions resulted in market inefficiencies. Accordingly, antitrust policy should only be limited to prohibiting price fixing or market division whereas the rest of the market dynamics should function independently. In 1976, Congress passed the Hart-Scott-Rodino Antitrust Improvements Act, which required prescreening of mergers and acquisitions over a certain amount of total assets to strengthen regulatory power over mergers and acquisitions (Sawyer, 2019).

From the 1990's to today, which is known as the Post-Chicago Period, the courts are taking into consideration behaviorism, game theory, and economic modeling, that the Chicago model was ignoring in their decision-making processes (Sawyer, 2019). One of the most important court cases of this period is Microsoft vs Netscape where the court has decided that Microsoft's intent was to monopolize the industry. As a result, Microsoft shared its programming interface with third parties (Sawyer, 2019). On the other hand Apple Inc. in 2013 was found guilty of price-fixing and orchestrating a "horizontal conspiracy among the publisher defendants to raise eBook prices" forbidden by the Sherman Act, and an injunction was issued. Another tech giant facebook is in a legal battle since July 2019 due to the monopolization concerns by the acquisition of Instagram and Whatsapp and therefore controlling an immense portion of the social media sector, as well as Amazon Inc. is in the same shoes for predatory pricing and discrimination against rivals which could lead to monopolisation (Wiener, 2020).

Although Google used "Don't Be Evil" as an ethical framework coined in 1999 by one of Google's first engineers, Amit Patel, and although later in 2015 as it established Alphabet as its parent company, it transformed into "Do the right thing" Google was under inquisition by the accusation that it exploited the market power as Google products and platforms emerged ahead of the competitors in its search engines (Wiener, 2020). In 2021, there were four antitrust lawsuits lodged against Google by 
U.S. government enforcers. The final one is alleging the company abused its power over app developers through its Play Store on Android (Feiner, 2021)

With the development of digital platforms that are used globally, antitrust policies and laws will remain as a major issue (Sawyer, 2019). Similar lawsuits are also happening in Europe thru the European Commission's Directorate General for Competition. However Europe is taking a different approach with respect to big digital platforms such as Google, recent enforcement decisions suggest that DDirectorate General for Competition officials are using a precautionary antitrust philosophy. This approach, based on the precautionary principle, seeks to prevent potential monopoly abuses in their incipiency by sanctioning business conduct without the need to show that it is causing any actual or likely consumer harm (Abbott, 2021).

"Don't be evil" or in reverse "Do the right thing" and care for people, and our planet is a simple dictum. Easy to follow if the system components, namely corporations, are structured and have features to do just that. Whatever the current intention or ethical framework, when these system components, namely corporations are operating under a shareholder profit maximisation and limited liability system the way they behave necessitates state intervention to protect people and the planet from their evil bad behavior. To ensure today's societal and planetary needs are met, before enforcing antitrust legislation, we need to ask if the reasons for the need of antitrust enforcement is the evolutionary roots and the constitution of modern companies, whether they be energy of internet technology companies.

\section{Current Situation and Reform Efforts}

The company law that legitimizes the existence of a "lifeless but immortal" entity with the sole purpose of creating more and more profits through exploitation of nature and society is simply scary. Today with their murky past profit maximising limited liability companies embedded in a neoclassical or neoliberal economic context have only caused suffering both for people and for the planet. This has naturally led movements to reform companies as they are or a search for alternatives. Let us explore these reform attempts and the alternatives as they are formulated. We will start with the most classical attempt of corporate social responsibility, then move to the polluter pays principle as an environmental economics policy tool, and to the once very popular stakeholder value creation. Afterwards we will go into more radical critiques and proposals of degrowth and solidarity economics, commons movement, peer-to-peer networks. Finally we will bring together a viable alternative based on social enterprises and an ecosystem approach called the prosumer economy. These 
will inform us not only about the problems but also the needs of today's challenges, leading to a new company law.

\section{Corporate Social Responsibility}

The concept of Corporate Social Responsibility ("CSR") was first addressed in the early 1930's. However, it may be argued that philanthropy was an earlier version of the CSR before the 19th century (Carroll, 2009). It should also be noted that, prior to the 1900's, in some cases, corporate contributions were perceived as giving away the stakeholder's assets/money without their approval (Carroll, 2009). For example, in the case of West Cork Railroad Company in 1883 in Great Britain, when the company wanted to give compensation to its employees at the time of the dissolution, Lord Justice Byron ruled that the Board of Director's job was to spend money on the benefits of the company and not to do charity (Carroll, 2009). Nonetheless, starting from the 1930's, corporations have been perceived as institutions with social responsibilities (Carroll, 2009). For example, in 1939, M. Clark wrote Social Control of Business, and in 1940, Theodore Krepp wrote Measurement of the Social Performance of Business (Carroll, 2009).

According to Patrick Murphy, there are four CSR periods (Carroll, 2009):

1. Philanthropic era: companies mainly donated to charities (before 1950's)

2. Awareness era: more recognition of overall corporate responsibility and involvement in community affairs (1953 - 1967)

3. Issue era: companies focused on issues such as racial discrimination, pollution, etc. (1968-1973)

4. Responsiveness era: companies are taking actions to address CSR issues, such as examining corporate ethics, altering boards of directors, social performance disclosures (1974 -1978, to today)

Today, companies are committed to CSR more than ever. For example, Blackrock, one of the biggest asset management companies in the world, announced that climate change will be an essential part of its investment strategy and it will not invest in companies whose more than $25 \%$ of revenues are driven from coal. Goldman Sachs announced that the company will spend 750 billion USD on sustainable finance in the next 10 years. Sustainable finance takes into account the environmental, social and governance (ESG) considerations when making decisions in the financial sector (Overview Of Sustainable Finance, 2020).

As benevolent as these facts sound, there is a question that rises from this topic. How can the sincerity of these benevolent actions by companies be ensured given 
that the CSR they are doing would enhance their public relations and make them more eligible for the investors, given the aforementioned examples? Or worse, could CSR be a way to cover up and superficially compensate for wrongdoings? Imagine a coal company polluting the air, then helping lung diseases. Such hypocrisy is pervasive, yet sometimes invisible under veneer and manipulative disguise. Despite the possibility of CSR being an effective way for companies to give back to society, it is highly open to abuse from companies.

In conclusion, CSR has come a long way in society, and is now in danger of the misconduct of some companies or is looked upon as green and all other colors of washing. Just the fact that we have to ask ourselves whether CSR is sincere or manipulative is an indication that again it is the corporation's structure and features that are in need of change, as no one asks in a cynical way whether it is profitable or not. If it wasn't it wouldn't exist. In a similar way a company ought not to exist in our eyes if it was not benefiting people or the planet.

\section{Polluter Pays Principle}

Another environmental reformist move is the polluter pays principle ("PPP"), one of the main principles in the 1992 Rio Declaration, stating that those who produce pollution should bear a cost. This cost is expected to prevent or reduce the damage caused by the pollution to human health and to the environment. In essence it is an environmental economics policy tool.

The history of PPP dates back to 1972 when it was first mentioned as a recommendation by the OECD and it was reaffirmed in 1974 ("Workshop On EU Legislation Principles Of EU Environmental Law: Poluter Pays Principle" 2012). The European Union reacted to the OECD recommendation by including the idea in the Environmental Action Program (1973-1976) and as Article 191(2) in the Treaty of the European Communities in 1987.

In 1992, it was stated as Principle 16 in the UN Declaration on Environment and Development ("Workshop On EU Legislation Principles Of EU Environmental Law: Poluter Pays Principle" 2012). In the 1992 Rio Declaration, the PPP was defined as pollution prevention and control measures. Today, the scope is broader with a liability on damage caused. In other words, if damage is done to the environment, the polluter is liable to pay the costs related to the damage. Furthermore, today there is also a broader understanding of producer responsibility. The pollution control is extended to cover the impact of the product during its whole life cycle, rather than 
the control at the source only ("Workshop On EU Legislation Principles Of EU Environmental Law: Poluter Pays Principle" 2012).

The PPP assumes that the polluter will reduce pollution if the costs it will pay for polluting is bigger than the benefit it will get from continuing to pollute. The polluter is also incentivized to reduce its risks in pollution by the costs he will have to otherwise pay on precautionary measures. The polluter also has to pay for the clean-up costs when an environmental damage takes place.

The polluter refers to a polluting activity but also covers those who cause risks for the environment even if pollution has not occurred yet. For example, in the Erika oil spill case in 2008, the European Court of Justice decided that the producer of hydrocarbons was responsible for the damage that occurred in the sea due to the accident. On the other hand, the user of the product indirectly pays when pollution control costs are reflected in the price ("Workshop On EU Legislation Principles Of EU Environmental Law: Poluter Pays Principle" 2012). Some countries like India, Taiwan, Malaysia, Chile, South Africa etc. also hold the government liable to compensate promptly for the victims' damages. The polluter reimburses the government for the payment later (Luppi et al, 2012).

To implement PPP, there are three types of instruments (Workshop On EU Legislation Principles Of EU Environmental Law: Poluter Pays Principle, 2012):

1. Command and control law: licensing, prohibitions, emission limit values etc.

2. Market based instruments: taxes, liability rules, subsidies etc.

3. Soft law: environmental management systems (ISO 1401), voluntary agreements, labelling etc.

Although PPP is a strong mechanism trying to minimize environmental damage, there are also some disadvantages in its implementation. First, it is unfair that the user bears the cost of pollution costs that are reflected in the product's price. The economic burden, through the extra charges companies reflect on the price of products, is on the consumer instead of the manufacturer; thus, the PPP is not effective. The companies are able to pollute the environment without significant economic repercussions, therefore, their environmentally degrading actions proceeds to damage the world. Also, there is a time lag between the time of the damage and the decision on the court case. The judicial delays negatively affect the impact of PPP. This hinders the disincentive characteristic of PPP as the repercussions of the damage caused loses impact. PPP also commodifies pollution as something that can be traded and put into a price tag. Furthermore, in contexts where there are no strong institutions, it creates disincentives for corporations that are law-abiding, and creates migration of business into less enforced territories. 


\section{Value Based Approaches - Creating Stakeholder Value}

According to Milton Friedman's well-known shareholder theory, in a capitalist economy, a company should maximize value for his shareholders by maximizing its profits and continuing its growth (Ferrero et al., 2014). Also, this theory states that "the only social responsibility of business is to increase its profits, a position now known as the shareholder model of business" (Ferrero et al., 2014). This shareholder theory has been adopted in the business world for a long time. However, in the last decades, another idea surged in the business world about creating not shareholder, but broader, stakeholder value, instead. Edward Freeman's stakeholder theory states that a company's stakeholders are anyone affected by that company: customers, employees, shareholders, suppliers, environmental groups, local communities, etc (Freeman, 2001). In his article titled "Strategic Management: A stakeholder approach" Freeman defines stakeholders as "those groups who can affect or are affected by the achievement of an organization's purpose" (Freeman, 2001). In this theory, the corporate environment is an ecosystem where all the stakeholders need to be satisfied for the success and the sustainability of the company in the long term.

In their article named "Reviewing the Stakeholder Value Creation Literature: Towards a Sustainability Approach", Tapaninaho and Kujala summarize their findings on the extensive research review on the articles that had been written on creating stakeholder value within the last 30 years (Tapaninaho and Kujala, 2019).

There have been extensive academic studies on creating stakeholder value in the past three decades. The majority of these academic studies analyzed the "multiple value perspective" rather than the "economic value perspective" (Tapaninaho and Kujala, 2019). On the other hand, there is not a major distinction between the number of studies focusing on the "focal firm perspective" vs "stakeholder orientation" (Tapaninaho and Kujala, 2019). In their article, Tapaninaho and Kujala suggest that future research should focus on several topics as stated below :

"We suggest that, with respect to sustainability, future research should consider the dynamic, systemic, and multilevel nature of stakeholder relationships and collaboration. Additionally, a more versatile understanding of value and value creation, as well as a broader comprehension of stakeholders and their needs, should be incorporated into future research. Finally, conceptualising sustainability and the normative core of sustainable business, as well as elaborating on the purpose and role of business regarding 
sustainability, are interesting focus areas for future research"

(Tapaninaho and Kujala, 2019).

Additionally, it is argued that "broadening the concept of value, so as to give access to other dimensions" is the most significant issue to be focused on rather than "adding" other types of value next to economic value (Argandoña, 2011). In the article named "Toward a Relational Stakeholder Theory: Attributes of Value-Creating Stakeholder Relationships," it is proposed that value-creating stakeholder relationships have three critical attributes: joint interests, ability to collaborate, and trust. These attributes are elements or characteristics of relationships between the firm and its stakeholders, not attributes of stakeholders" (Kujala et al., 2016). This can be interpreted as the stakeholder system, as opposed to the profit-centered shareholder system, is more conscious of everyone that is involved in and affected by the companies actions, strengthening the relationship between the company and its stakeholders, and optimizing value for all organisms and beings in this ecosystem. This approach has enormous potential for today's problems, yet it is not written in law, nor is it a requirement, hence has no widespread implementation.

\section{Degrowth}

A major reformist may be even revolutionary, self proclaimed, movement is degrowth. Degrowth has been discussed since the beginning of the twenty-first century aiming to accomplish social and ecological sustainability.

André Gorz used the term 'décroissance' (degrowth in French) for the first time in 1972 and started the debate on degrowth with his question: "Is the earth's balance, for which no-growth - or even degrowth - of material production is a necessary condition, compatible with the survival of the capitalist system?' (D'Alisa et al, 2015). Gorz was inspired by Nicholas Georgescu-Roegen, who is referred to as the "intellectual pioneer of ecological economics and bioeconomics" for his work that was published with the title 'Entropy Law and the Economic Process' in 1971 (D'Alisa et al, 2015).

The second wave of the degrowth movement started in France in the early twenty-first century. In 2002, the first international conference on degrowth titled "Défaire le développement, refaire le monde" took place in Paris with 800 participants where the degrowth movement activists of Lyon and the academic world came together (D'Alisa et al, 2015). Since then, research on degrowth has expanded to the extent that degrowth has become a teaching topic in the universities (D'Alisa et al, 2015).

According to Demaria et al. (2013), degrowth is more than an economic concept: 
"It brings together a heterogeneous group of actors who focus on housing and urban planning, financial issues and alternative money systems, agroecology and food systems, international trade, climate justice, children's education and domestic work, meaningful employment and cooperatives, as well as transport and alternative energy systems. We have argued that degrowth could complement and reinforce these topic areas, functioning as a connecting thread (i.e. a platform for a network of networks)."

Governments have preferred to focus on sustainable growth rather than degrowth so far in order to avoid the "adverse" economic and political implications of degrowth. However, since sustainable "green growth" has its limitations as to the resources required, researchers are continuing to work on developing integrated ecological-economic models to simulate the effect of degrowth. For instance, Peter A. Victor analyzed such a degrowth model in his book named "Managing Without Growth: Slower by Design, Not Disaster" (Kallis et al., 2018). As a result of these models, researchers are concluding that although implementation of a degrowth strategy may seem like a utopia to some economists and politicians, a well-planned transition to this model may be a good solution to the current sustainability problems in our world (Kallis et al., 2018).

In their article "Successful Non-Growing Companies," Liesen, Dietsche, and Gebaue analyzed ten successful small and medium-sized companies ("SME") that they define as Successful Non-Growing Companies (SNC) that publicly announced that they are following a no-growth policy. Their analysis, although it is a small sample size, showed several characteristics of SNC's as summarized below (2014):

- There can be many different motivations for a no-growth strategy such as work-life balance, environmental and social motivations, risk aversion, related costs of organizational structure.

- They focus on "better" rather than "bigger."

- Their key performance indicators (KPl's) measure product quality, efficiency of processes, working conditions, the social and environmental value of products, etc.

- They focus on innovation especially in the area of resource efficiency and aim to further reduce the total environmental impacts of the company

In his work that was published in 2005, titled "Small Giants: Companies That Choose to Be Great Instead of Big" Burlingham states the seven qualities of successful no-growth companies based on his research as follows (Liesen, et al 2014):

- Questioning usual measures of success,

- Refusing taking on external capital,

- Being deeply connected with their local community, Having close and long-term relationships with suppliers and customers,

Creating a special work atmosphere, 
- Having innovative management structures and

- Are being run by a person that shows strong identification with the purpose of the company.

According to Burlingham (2005) who analyzed twelve successful no-growth companies do not aim to maximize profits as their primary target. Instead, they are "interested in being great at what they do, creating a great place to work, providing great service to customers, having great relationships with their suppliers, making great contributions to the communities they live and work in, and finding great ways to lead their lives. " (Burlingham, 2005)

In another research made on 100 companies in 2012, White and White summarized their findings on the motivations of the no-growth company owners as follows:

- avoidance of risk, e.g. risk associated with investments needed to expand a business

- maintenance of lifestyle, e.g. longer working hours and less family time when a business is expanded

- avoidance of regulation, e.g. laws that become applicable to companies with a certain size

- unwillingness to delegate responsibilities, e.g. unwillingness to transfer decision-making authority.

How can a firm apply degrowth strategy is explained in "Why "De-growth" Shouldn't Scare Businesses" by Thomas Roulet and Joel Bothello (2020), which was published in Harvard Business Review in Feb 2020. In this article, Roulet and Bothello state that despite political and corporate resistance, degrowth movement already has been started on the consumer demand side and suggest large companies three strategies that they can adopt based on their research on companies leading the degrowth movement (Roulet and Bothello, 2020):

- "Degrowth-adopted product design": products with longer lifespans, modular or locally produced. For example, The 30 Year Sweatshirt produces sweatshirts that are high quality, durable and against the fast fashion principles.

"Value-chain repositioning": firms delegate stakeholders to certain stages of the value chain. For example, Lego launched marketplaces for trading used products.

- "Degrowth-oriented standard setting": For example, Patagonia offers a worn-wear store where free repairs for their products as well as for other manufacturers' products are offered. Walmart, Nike and H\&M asked for advice from Patagonia and they are following the trend set by Patagonia with the repair offer. Tesla, also, released its electric vehicle patents in 2014 to standardize the technological platform in the industry. 
Increasing concerns on the climate and biodiversity crises is triggering the changing consumption patterns of the consumers and driving degrowth. Companies will have to adapt to this consumer-driven degrowth as a new opportunity. Businesses that respond successfully to this demand will be able to sell "better products" rather than "sell more" and they will be able to satisfy their customers and protect the environment. Will they be able to maintain this position if consumers are engaged in price optimisation, or how many customers can afford to do so? Therefore a level playing field, where every company is obligated to operate under degrowth features is rising as a necessity.

\section{Solidarity Economics}

Another antithesis to today's company structure is the "solidarity economy" that prioritizes the welfare of people and environment, rather than profits and growth (Kawano, 2018). Miller defines solidarity economy as "a woven patchwork of many diverse economies that are centered on life-values instead of profit-values" (Miller, 2004).

According to the U.S. Solidarity Economy Network, there are five principles of solidarity economy as stated below:

- solidarity, cooperation, mutualism;

- equity in all dimensions (e.g., race, ethnicity, nationality, class, and gender, etc.);

- participatory democracy;

- sustainability; and,

- pluralism

In the context of solidarity economics, "pluralism" means that there may be "multiple paths" to reach a "just and sustainable world". All of these five principles should be present in a successful implementation of solidarity economics (Kawano, 2018).

Today, the current economic theory is based on Homo economicus who is self-interested, and competitive (Kawano, 2018). In other words, Homo economicus is motivated with individualism rather than the well-being of the common good, the community and the environment. However, research highlights that human nature is not as simple as the assumption in Homo economicus and that it has both "self-serving" and "solidaristic" characteristics. In fact, Elinor Ostrom's work, showing that forests, fishing grounds, etc managed by their stakeholders performed better than the ones that were managed by private owners or the state, won the Nobel Prize in 2009. On the other hand, Ostrom also highlights that cooperative, 
collective systems must also address the self-interested nature of the people to be resilient (Kawano, 2018).

In his article titled "Solidarity Economics Strategies for Building New Economies From the Bottom-Up and the Inside-Out," Miller (2004) describes the transformation from the current capitalist system to solidarity economics as an "economic independence movement":

This process begins not with "experts," but with concrete grassroots organizing efforts. This will not be a revolution in which the "vanguard" with the Truth takes power and then imposes a new utopia on everyone else. This is a revolution of secession from the world of both capitalists and bureaucrats-an economic independence movement. We begin with the places in which we have already achieved independence and solidarity, and we build our movements from there-revolution from the bottom-up and the inside-out.

Some examples for solidarity economics that is present in our current lives are: "worker cooperatives", "libraries", "parks", "water fountains", "community supported agriculture", "carpooling", "no-interest loans between friends and family", "community development credit unions", "volunteer ambulance squads", etc. (Miller 2004).

In his article titled "Social and Solidarity Economy: Is There a New Economy in the Making?" Utting et al. (2014) provide statistics on social economy size, such as:

- Preliminary results from the Global Census on Cooperatives of the United Nations Department of Economic and Social Affairs (UN DESA) indicates that globally there are 761,221 cooperatives and mutual associations with 813.5 million members, 6.9 million employees, USD 18.8 trillion in assets and USD 2.4 trillion in annual gross revenue.

- Mutual benefit societies provide health and social protection services to 170 million people worldwide.

- The global certified fair trade market amounted to EUR 4.8 billion (USD 6.4 billion) in 2012 (excluding Fair Trade USA sales) and involved some 1.3 million workers and farmers in 70 countries.

- In Europe, approximately two million SSE organizations represent about 10 percent of all companies and employ over 11 million people (the equivalent of 6 percent of the working population of the European Union).

Solidarity economy is expanding in the world, as it is definitely an alternative in current day realities to the existing profit-maximising companies with limited liability. 
Yet it operates in an unfair environment, where financial incentives are greater for investment in an environment of limited liability, where investors can easily go for larger returns. Solidarity economy is also facing some challenges and limitations with the other actors in the economy, e.g. states, market actors, social norms, etc. Furthermore, it also has internal challenges, e.g. infrastructure, participation, preferences of members, etc. The future of solidarity economy depends on solving these challenges with the help of public policy (Utting et al., 2014), and a strong favourable legal environment.

\section{Commons Movement and Critique of Companies}

One of the main contesters of privatization, corporations, and profit-maximisation for shareholder value is the Commons Movement. "Commons" are defined as the "products and resources that are created, cared for, and used in a shared way in a great variety of forms" by humans, and hence, means essentially everything under the sky (Euler and Gauditz, 2017). It was first used in England in 1215 where farmers were given access to their lord's lands and forests in "Magna Carta" (Aguiton, 2017). In his article on the "tragedy of the commons" written in 1968, Hardin argues that the overutilization of common resources is a leading cause of environmental degradation, and communities are not able to make rational agreements by themselves (Ostrom, 1990). He suggests that either privatization or the introduction of an external agent like the government is required to ensure proper management (Ostrom, 1990). However, Elinor Ostrom, (1933-2012) -- the first, and still, the only woman ever to receive the Nobel Prize in Economics in 2009 -- proves that this is not always the case. Even the "tragedy of privatization" takes place while trying to avoid the "tragedy of the commons" through privatization (Kim and Cho 2015). The profit maximization tendency and competition between the individuals or companies damage solidarity, the commons, and thus the environment (Caffentzis and Federici, 2014). For example, commercial interests weakened even the communication and sharing of knowledge among the scientists on their research work in the U.S. universities (Caffentzis and Federici, 2014).

The attention on the commons has been increasing lately and institutions like the World Bank are encouraging research studies on the commons (Caffentzis and Federici 2014). Nowadays, the self-governed commons model is a candidate to be "the third sector," after the public and private sectors (Caffentzis and Federici 2014). Furthermore, the commons movement is not only an important part of the economy but also a growing social and political movement. It is a new paradigm where the competitive, profit-oriented mindset of the capitalist system is to be replaced with a 
"more humanistic, environmentally aware and holistic world view". The argument on the tragedy of the "anti-commons" states that the excess privatization in the economy and the profit-oriented focus of the private companies are the main causes for the many problems existing in our world today, including environmental degradation and the prevention of collective action to achieve a common good An example for such prevention of collective action for the benefit of the common good is the limitations caused by the patents in the biomedical knowledge hindering further research on cures for malaria (On the Commons, 2021).

Bollier (2014) argues that the global commons movement is much stronger than a traditional movement that is driven by an ideology because its driving force is its participants' unity and commitment to self-governance. In the past few decades, one of the most significant trends in the digital commons was the expansion of the usage of the internet where knowledge sharing and collaboration was introduced. Wikipedia and free/open source software programs are examples of such successful digital commons. Bollier (2014) highlights that the common motivation behind these digital commons is the willingness to co-produce and innovate without the intervention of the traditional market and the state. Furthermore, he argues that the cooperation on open networks is more efficient than the markets (Bollier, 2014). The motivation behind these successful commons examples on knowledge sharing and software production is also applicable to other areas of the economy such as resource management and production. In the article "The Commons - Prosperity by Sharing," Helfrich et al. (2010) argue that commons will have a prevailing importance in the future:

"Markets, as they exist today in the commodities economy, will play a less significant role in the future, while the commons and the open communities of commoners will become the centre of life. For this, a new understanding of the market and a new understanding of management must evolve, in which the commons are not primarily the object of private acquisition, but are used, preserved and further developed for the benefit of all."

The critique of the commons movement makes it clear that we need a different form of corporation than what we have today, in which the economy should be structured on participation, self-governance, and shared resources, rather than corporate profit maximisation.

\section{P2P - Peer to peer}

Enabled by digital platforms, as an alternative to corporate structures, peer-to-peer ("P2P") business models are becoming increasingly significant in the economy. In 
P2P computing networks, computers interact with each other where the presence of a server computer is not required and peers are "equipotent participants" in the network (Bauwens, 2019). Considering that there are users using these computers in a P2P network, it can be argued that the users leverage on this technological tool enables them to collaborate with each other in order to create value (Bauwens, 2019), not necessarily profits.

P2P can be defined as "a mode of relationship that allows human beings to be connected and organized in networks, to collaborate, produce and share" (Bauwens, 2019). In this context, peer-to-peer economy is also known as "collaborative economy," "collaborative consumption," and "sharing economy" (Bellotti et al., 2015). In capitalism, the market price is the main driver of the system; whereas, in peer-to-peer production the main driver is mutual coordination.

There is also a strong relationship between peer to peer systems and the commons where $\mathrm{P} 2 \mathrm{P}$ is the enabler, creating the optimal conditions for communing, David Bollier defines the characteristics of the commons as "a shared resource, co-governed by its user community according to the rules and norms of that community" (Bauwens, 2019). In this context, the internet is offering an efficient platform for social transformation where the roles of the market and the government are less important, and the ease of "many-to-many" communication is enabling self-organization and self-governance on a global scale (Bauwens, 2019). In other words, peer to peer systems are enabling the implementation of the self-governed commons on a global scale, diminishing the role of third-party actors such as the government and private companies. Bauwens highlights the potential social transformation that can take place with the growth in the P2P as follows:

As a result, the emergence and scaling of these P2P dynamics point to a potential transition in the main modality by which humanity allocates resources: from a market-state system that uses hierarchical decision-making (in companies and the state) and pricing (amongst companies and consumers), towards a system that uses various mechanisms of mutual coordination. The market and the state will not disappear, but the configuration of different modalities - and the balance between them - will be radically reconfigured (Bauwens, 2019).

Going one step further, Eisenstein (2011) sees the internet as an example of a "participatory gift economy." In a P2P network, there is no distinction between producers and consumers; when we mutually share information, recommendations, songs, etc. in our online network, we do not charge anyone for the information we provided, making it a gift economy. Furthermore, most of the websites provide free content, as well (Eisenstein, 2011). 
P2P networks are in resistance to corporate structures, aligning themselves with commons, and hence, are a movement towards reinventing how business can be done other than forming companies that rely on profits to share with shareholders.

\section{Social Enterprises}

The evolution of company laws lead to the forming of companies that predominantly focus on profit maximization for shareholders, and limiting liability for investors. As stated before this system is far from meeting the needs of today's society, and it's even seriously damaging Earth's life support systems. Social enterprises emerged as a response to make up for these insufficiencies of the existing system by offering solutions through the creation of sustainable social value and environmental protection (Bayraktar et al. 2014).

The emergence of social enterprise as a sector dates back to the 1970's, when the high oil prices of 1973 resulted in an economic downturn. In the United States, the cuts in government funding for non-profit organizations due to the economic downturn together with the growing number of nonprofits competing with these funds and rising social needs, shifted the focus of socially responsible organizations to be self-sufficient in funding their operations and resulted in the establishment of social enterprises. On the other hand, in Europe, the main cause of the establishment of social enterprises was the creation of work opportunities to fight with the high unemployment during the economic downturn. The governments strongly supported the establishment of the social enterprises and they treated the social enterprises as partners in solving social problems in Europe (Poon 2011).

OECD and European Commission (Antonella and Clarence, 2013) defines a social enterprise as being "an operator in the social economy whose main objective is to have a social impact rather than make a profit for their owners or shareholders." Solidarity, focus on people rather than profits, and participative governance are the main values that should be present in social enterprises (Antonella and Clarence, 2013).

Social enterprises are increasingly getting involved with the commons to contribute to the development of the community and to create value in their economic activities (Meyer, 2020). Berkes and Davidson-Hunt (2007), in their article titled "Communities and Social Enterprises in the Age of Globalization" state that commons-based social enterprises in rural areas are successfully interacting with global actors. The social enterprise structure enables the rural commoners to secure tenure for the resources and to make direct decisions regarding their management (Berkes and Davidson-Hunt, 2007). Svendsen and Ueda (2002) argue that a non-profit organization run by a social entrepreneur performs much better than a 
profit organization operated by a business entrepreneur on the social objective of providing the global public good and, thus, social enterprises can play an important role in preserving the global commons. Furthermore, social enterprises can also leverage the benefits of the sharing economy (peer to peer economy) by connecting people and making sharing more efficient (Roh, 2016).

Social enterprises operate in an open and responsible manner through a participative governance structure where employees, consumers and stakeholders affected by its commercial activities are involved, and provide goods and services for the market in an entrepreneurial and innovative fashion to use their profits primarily to achieve social objectives (Antonella and Clarence, 2013). Accordingly, business entrepreneurs measure performance in terms of profit whereas social entrepreneurs measure "positive returns to society" (Zheliazkov and Stoyanov, 2016). However, aiming to achieve social, cultural and environmental progress does not necessarily mean that social enterprises should not be making profits (Zheliazkov and Stoyanov, 2016), it means that they should be reinvesting profits for sustainability and scaling of impact.

Social enterprises can be in several forms such as solidarity enterprises, co-operatives or limited liability social co-operatives, collective interest co-operatives (in Italy, France, Spain, Portugal and Greece), social purpose or collective interest companies (Belgium) and community interest companies (United Kingdom). These different organizational forms can be summarized in three different models as the "co-operative," the "company," and the "open form" where the legislation does not define a legal form but only defines the criteria to be considered as a social enterprise (Antonella and Clarence, 2013).

As social enterprises are organizing into networks, such as the Ashoka Foundation where more than 92 countries more than 3,500 fellows (Ashoka: Everyone a Changemaker, 2021) are coming together, or as in Good4Trust.org established in 2014 where hundreds of social entrepreneurs convene, a new form of business entity is emerging (British Council, 2019). These entities, rather than competing with each other, are building solidarity and helping each other to increase their social and ecological impact.

\section{Prosumer Economy}

These new corporate entities whether be a successful small and medium-sized company ("SME") that defines itself as a slow company, or non-growing company (SNC), a solidarity economy cooperative, a commons institution, a P2P Network, a social enterprise or simply an NGO owned commercial entity, all are coming together in a prosumers economy. All these entities can essentially be ecologically and 
socially just businesses by law, whose legal foundation has already been articulated as social enterprises or have developed criteria as certified benefit corporation (Honeyman and Jana, 2019).

Prosumer economy is a macroscale circular economy with minimum negative or positive ecological and social impact, an ecosystem of producers and prosumers, who have synergistic and circular relationships with deepened circular supply chains/networks, where leakage of wealth out of the system is minimised. These networks are growing fast and becoming prevalent, together they are much more adapted to today's social and environmental reality (Özesmi, 2019).

This new economic ecosystem, the prosumer economy, operates like a forest ecosystem, without harming the planet and even helping regenerate healthy natural ecosystems and biodiversity and reducing carbon in the atmosphere. This new form of economic organisation is our only way to survive. However, for such a system to take hold and encompass our economic production both a policy environment that encourages all these new forms of existence as well as a new legal environment is needed. A new company law is required to embrace this new form, and part from the old - which has proven to be destructive.

\section{A new company law}

What might this new company law look like? For this purpose we have taken the Turkish Company law as an example. As you must have noticed in our tour around the world, the evolution of company laws started predominantly to be benevolent to society and later metastasized in the same form around the globe. Hence the general direction of what we propose here will be relevant to all national and international laws.

It is quite interesting that we can find nowhere in the current Turkish Commercial Code 6102 (Turkish Commercial Code 6102, 2011) the raison d'etre of companies, not even that they need to have a profit. According to the Turkish Commercial Code, the limited partnership and unlimited partnership are individual companies and are founded to run a commercial business. Also cooperatives may be founded to protect the specific economic interest and mutual support needed for the occupations of their members.

Articles 331 and 573 of the Turkish Commercial Code 6102 states that joint stock companies and limited partnerships may be incorporated for any subject and economic purpose that are not forbidden by the law. There is no explicit requirement that within the current regulations joint stock companies and limited partnerships 
have to make a profit and distribute this profit to their partners. However there is an expectation, as they are termed "commercial" that they need to turn profits, and there are articles on profit distribution. However the interest of the state comes in and enforces this, within the goal of obtaining taxes and state tax officials threaten companies with closure if they do not turn in profit. However this is open to interpretation and court cases. The only real limitation is that they must not be illegal. Therefore we propose the following changes, as underlined:

\section{ARTICLE 331}

Joint stock companies may be established for any economic purpose that is beneficial for the planet and the people on subjects that is not prohibited by law.

Also conditions of incorporation inline with changes in Article 331 have consequences for Article 339.

\section{ARTICLE 339}

(1) The articles of association are required to be in written form, and all signatures of the founders need to be approved by the notary public.

(2) On the articles of association, the matters bellow are written:

a. Trade name and where the headquarter would be located.

b. The subject of the company specified and defined with essential points.

c. The specific purpose on how the company is being beneficial for the planet and people.

The statement of the purpose of benefiting the planet and people is by itself not sufficient as it also needs to be proven to society, which gives the company rights to exist as an entity. Therefore Article 397 needs to be amended as underlined:

\section{ARTICLE 397}

(1) Financial statements of joint stock company and the enterprise system are audited by the auditors according to Turkey Auditing Standards, that are harmonic with the international auditing standards. The audit includes whether the financial, benefit to planet and people information, in the annual activity report of the board, is consistent with financial, ecological and social statements, and reflects the reality. 
This obviously will also expand financial auditors expertise areas to include ecological and social issues, and hence require the amendment of the scope of Turkey Auditing Standards as well.

Given that a company does not comply with this purpose set in the articles of association, a non-compliance or the impossibility to comply with this purpose would lead to the liquidation of the company,serve its function to benefit the planet and people, it may lose its raison d'etre and hence be dissolved. The dissolution of companies is dealt within Article 529 and hence we propose the following amendment:

\section{ARTICLE 529}

(1) Joint Stock Company;

[...]

b. The occurrence of the field of operation, or the fulfilment of the benefits to the planet or people, or when the field of operation, or benefits to planet and people becomes impossible,

$[\ldots]$

would liquidate.

If an additional and more precise subsection is needed that could be added to Article 529 about joint stock company liquidation.

The amendments we proposed pertaining to the purpose and content of articles of association, auditing and dissolution for joint stock companies is also valid for limited companies. To be more precise:

\section{ARTICLE 573}

(1) A limited company may be established by one or more real or legal persons under a commercial name; the capital is definite and divided into shares.

(2) The shareholders are not liable for the debts of the company, they are obliged to pay only the capital shares they have committed and to fulfill the additional payment and performance obligations stipulated in the company contract.

(3) A limited company may be established for any economic subject and purpose that is beneficial for the planet and the people on subjects and that is not prohibited by law.

\section{ARTICLE 575}

(1) The articles of association is required to state the specific purpose on how the company is being beneficial for the planet and people, be in written 
form, and all signatures of the founders needs to be approved by the notary public.

As these conditions on the purpose of companies are added we envision that Auditing Standards would also be established including reporting and measuring ecological and social impacts of a company. This will also contribute to more transparency and accountability towards the public and for the benefit of the planet.

\section{Conclusion}

People on this planet gave some entities the right to exist and legal standing, because these entities were needed as higher forms of organisations for societal needs. In the middle ages animals as entities had rights and responsibilities in the courts and could be put on trial (Klopfer and Polemics, 1988). Hence the company as an organism is not a far fetched analogy. We also gave companies rights and responsibilities as an entity and legal standing before the courts because they initially served society. As animals don't have the right to stand in court anymore, we could also revoke it for companies. Especially if most of them today are the driving force behind a consumerism that is killing our future prospects to exist on this planet.

Yet companies can also be very useful as higher forms of organisations producing anything from public health medicines, and vaccines, to transportation vehicles, from water saving washing machines, to wind turbines, photovoltaic panels, and water heaters, you name it. So how do we ensure that they produce these goods and services for society, without exploiting people and the planet. Their economic activity today is destroying our planet's life-support systems. Therefore, many nations, the United Nations, civil society organisations have all tried to reform companies. They have made international agreements, put on more policy restrictions, and redefined economic relationships. These efforts include antitrust laws, instituting polluter pays principle, value based approaches, proposing Degrowth, and Solidarity Economics, building Peer-to-Peer, and Social Enterprises, and finally a whole new macro scale circular economy called the Prosumer Economy.

These efforts, frameworks, and system proposals continue to be useful, and should continue, however they are not enough by themselves as the planet continues to deteriorate under the biggest biocide and human induced climate emergency threatening human civilization and maybe even existence. We have proposed that existing company laws need to be fundamentally revised to make it compulsory that companies may not only "not harm the planet and people", but that they have to 
actively demonstrate and prove that they are actually "benefiting the planet and people" by law.

\section{Acknowledgements}

We would like to thank Ece Satici, Hande Yavuz, and Fırat Kavlak for research. Ayhan Aktar, Neşet Kutluğ, Özlem Atabaş Tavares for comments, and Ashoka Foundation Turkey for inspirations.

\section{References}

"About The Commons | On The Commons". 2021. Onthecommons. Org. Accessed January 2021.

http://www.onthecommons.org/about-commons\#sthash.aigOmOH3.LICApZPT.dpbs.

"Ashoka; Everyone A Changemaker". 2021. Ashoka| Everyone A Changemaker. Accessed July 24. https://www.ashoka.org/en-tr.

Badaracco, Claire., 2018. Hudson's Bay Company. International Directory of Company Histories. In: encyclopedia.com. Available at (June 1, 2021):

https://www.encyclopedia.com/books/politics-and-business-magazines/hudsons-baycompany-1

European Commission - European Commission. 2020. Overview of sustainable finance. Available at:

https://ec.europa.eu/info/business-economy-euro/banking-and-finance/sustainable-fi nance/overview-sustainable-finance en (Accessed October 1).

"Türkiye'de Sosyal Girişimlerin Durumu." British Council Türkiye, British Council, 2019, www.britishcouncil.org.tr/sites/default/files/20190702_se_research_report the state _of_social_enterprise_in_turkey_tr_single_page.pdf.

Workshop On EU Legislation Principles Of EU Environmental Law: Poluter Pays Principle. 2012. Cooperation with National Judges and Prosecutors in the Field of EU Environmental Law , 2012.

https://ec.europa.eu/environment/legal/law/pdf/principles/2\%20Polluter\%20Pays $\% 20$ Principle revised.pdf 
Abatino, Barbara, Giuseppe Dari-Mattiacci, and Enrico C. Perotti. 2011.

"Depersonalization Of Business In Ancient Rome". Oxford Journal Of Legal Studies 31 (2): 365-389. doi:10.1093/ojls/gqr001.

Abbott, Alden F. 2021. "The Globalization Of Antitrust: History And Prospects". SSRN Electronic Journal. doi:10.2139/ssrn.3868267.

Aganin, Alexander, and Paolo Volpin. 2005. "The History Of Corporate Ownership In Italy". In A History Of Corporate Governance Around The World: Family Business Groups To Professional Managers. University of Chicago Press.

Aguiton, Christophe. 2017. The Commons, Systemic Alternatives, 30 Mar. systemicalternatives.org/2017/03/20/the-commons/.

Akbaş, Halil Emre, Serdar Bozkurt, and Kübra Yazıcı. 2018. "Osmanlı Devletinde Lonca Teşkilatı Yapısı Ve Yönetim Düşüncesi lle Karşılaştırılması". Muhasebe Ve Finans Tarihi Araştırmaları Dergisi, İşletme Tarihi Özel Sayısı, 165-202. https://dergipark.org.tr/en/pub/muftad/issue/38342/444232.

Akyılmaz, Sevgi Gül. 2008. "Osmanlı Devleti'Nde Yönetici Sınıf Açısından Müsadere Uygulaması". Gazi Üniversitesi Hukuk Fakültesi Dergisi 12 (1). https://dergipark.org.tr/en/pub/ahbvuhfd/issue/48129/608680.

Angelucci, Charles, Simone Meraglia, and Nico Voigtländer. 2020. "How Merchant Towns Shaped Parliaments: From The Norman Conquest Of England To The Great Reform Act". NBER Working Paper Series.

https://www.nber.org/system/files/working_papers/w23606/w23606.pdf.

Argandoña, Antonio. 2011. "Stakeholder Theory And Value Creation". SSRN Electronic Journal. Available at: https://ssrn.com/abstract=1947317 or http://dx.doi.org/10.2139/ssrn.1947317

Avi-Yonah,Reuven S. 2005. The Cyclical Transformations of the Corporate Form: A Historical Perspective on Corporate Social Responsibility. 30 Delaware Journal of Corporate Law 767.

Balla, Eliana and Noel D. Johnson. 2009. 'Fiscal Crisis and Institutional Change in the Ottoman Empire and France.' Journal of Economic History, 69(3), 809-45.

Barrow, Ian J. 2017. The East India Company,1600-1858. Indianapolis: Hackett. 
Bartolini, S. and Bonatti, L., 2003. Endogenous Growth and Negative Externalities. Journal of Economics, 79(2), pp.123-144.

Bates, Amanda E., Richard B. Primack, Paula Moraga, and Carlos M. Duarte. 2020. "COVID-19 Pandemic And Associated Lockdown As A "Global Human Confinement Experiment" To Investigate Biodiversity Conservation". Biological Conservation 248: 108665. doi:10.1016/j.biocon.2020.108665.

Bauwens, Michel. 2019. Peer to Peer. London: University of Westminster Press. DOI: https://doi.org/10.16997/book33

Bayraktar, Eda, Erhan Bozkurt and Uygar Özesmi. 2014. "Sosyal Girişimin Lafzı ve Ruhu”. Optimist, Girişim, İnovasyon, Yönetim, Yıl: 2, Sayı: 17, Istanbul.

Bellotti, Victoria, Alexander Ambard, Daniel Turner, Christina Gossmann, Kamila Demkova, and John M. Carroll. 2015. "A Muddle Of Models Of Motivation For Using Peer-To-Peer Economy Systems". Proceedings Of The 33Rd Annual ACM Conference On Human Factors In Computing Systems.

doi:10.1145/2702123.2702272.

Berkes, Fikret, and lain J. Davidson-Hunt. 2007. "Communities And Social Enterprises In The Age Of Globalization". Journal Of Enterprising Communities: People And Places In The Global Economy 1 (3): 209-221. doi:10.1108/17506200710779521.

Black, Antony. 2003. Guild And State: European Political Thought From The Twelfth Century To The Present. 1st ed. Routledge. ISBN 9780765809780

Blumberg, Phillip I. 1993. The Multinational Challenge To Corporation Law. New York: Oxford University Press.

Bollier, David. 2014. "The Commons As A Growing Global Movement". Blog. David Bollier News And Perspectives On The Commons.

http://www.bollier.org/blog/commons-growing-global-movement.

Brandon, Pepijn. 2017. "Between Company And State: The Dutch East And West India Companies As Brokers Between War And Profit" Chapter. In The Corporation: A Critical, Multi-Disciplinary Handbook, edited by Grietje Baars and Andre Spicer, 215-25. Cambridge: Cambridge University Press. doi:10.1017/9781139681025.011. 
British Council. 2019. "Türkiye'de Sosyal Girişimlerin Durumu".

https://www.britishcouncil.org.tr/programmes/education/social-enterprise-research.

Brooke, John L. 1989. The Heart of the Commonwealth: Society and Political Culture in Worcester County, Massachusetts, 1713-1861. Amherst: University of Massachusetts Press.

Burlingham, Bu., 2005. Small Giants: Companies That Choose to Be Great Instead of Big. Portfolio Hardcover.

Caffentzis, George, and Silvia Federici. 2014. "Commons Against And Beyond Capitalism". Community Development Journal 49 (suppl 1): i92-i105. doi:10.1093/cdj/bsu006.

Çağatay, Neşet. 1989. Bir Türk Kurumu Olan Ahilik. Ankara: Türk Tarih Kurumu Basımevi. ISBN: 9751601925

Campbell, Bruce A. 1975. "John Marshall, The Virginia Political Economy, And The Dartmouth College Decision". The American Journal Of Legal History 19 (1): 40. doi:10.2307/844581.

Cannon, John "Hudson's Bay Company." The Oxford Companion to British History. . Encyclopedia.com. (August 16, 2021).

https://www.encyclopedia.com/history/encyclopedias-almanacs-transcripts-and-maps /hudsons-bay-company

Carroll, Archie B. 2009. "A History Of Corporate Social Responsibility". Oxford Handbooks Online. doi:10.1093/oxfordhb/9780199211593.003.0002.

Carroll, William K, and J. P Sapinski. 2018. Organizing The 1\%: How Corporate Power Works. Halifax: Fernwood Publishing.

Cavanagh, Edward. 2011. "A Company With Sovereignty And Subjects Of Its Own? The Case Of The Hudson's Bay Company, 1670-1763". Canadian Journal Of Law And Society 26 (1): 25-50. doi:10.3138/cjls.26.1.025.

Chakraborty, S K, Verghese Kurien, Jittu Singh, Mrityunjay Athreya, Arun Maira, Anu Aga, Anil K Gupta, and Pradip N Khandwalla. 2004. "Management Paradigms Beyond Profit Maximization". Vikalpa: The Journal For Decision Makers 29 (3): 97-118. doi:10.1177/0256090920040308. 
Cicarelli, James. 2012. "Economic Thought Among American Aboriginals Prior To 1492". American Journal Of Economics And Sociology 71 (1): 77-125. doi:10.1111/j.1536-7150.2011.00817.x.

Çiftçi, Cafer. 2004. "Müşteri Memnuniyeti, Kalite Ve Osmanlı Esnafı". Uludağ Üniversitesi Fen-Edebiyat Fakültesi Sosyal Bilimler Dergisi 5 (7): 17-34. https://dergipark.org.tr/tr/pub/sosbilder/issue/23112/246861.

Cohen, Amnon (translated by Nurettin Elhüseyni). 2001. Osmanlı Kudüs'ünde Loncalar. İstanbul: Tarih Vakfı Yurt Yayınları.

Comack, Elizabeth. 2018. "Corporate Colonialism And The "Crimes Of The Powerful" Committed Against The Indigenous Peoples Of Canada". Critical Criminology 26 (4): 455-471. doi:10.1007/s10612-018-9414-y.

Conac, Pierre-Henri. 2005. The French and Dutch East India Companies in Comparative Legal Perspective. In Gepken-Jager et al. (eds), VOC 1602-2002: 400 Years of Company Law. Deventer: Kluwer.

Cooke, Colin A. 1950. Corporation, Trust and Company: An Essay in Legal History. Manchester: Manchester University Press.

Corlett, Richard T., Richard B. Primack, Vincent Devictor, Bea Maas, Varun R. Goswami, Amanda E. Bates, Lian Pin Koh, Tracey J. Regan, Rafael Loyola, Robin J. Pakeman, Graeme S. Cumming, Anna Pidgeon, David Johns, and Robin Roth. 2020. "Impacts Of The Coronavirus Pandemic On Biodiversity Conservation". Biological Conservation 246: 108571. doi:10.1016/j.biocon.2020.108571.

Dalrymple, William. 2019. The Anarchy:The Relentless Rise Of The East India Company. Bloomsbury Publishing PLC.

D'Alisa, Giacomo, Federico Demaria, and Giorgos Kallis. 2015. Degrowth: A Vocabulary for a New Era. Abingdon: Routledge. ISBN 9781138000773

Damodaran, Vinita. 2006. "Famine In Bengal: A Comparison Of The 1770 Famine In Bengal And The 1897 Famine In Chotanagpur". The Medieval History Journal 10 (1-2): 143-181. doi:10.1177/097194580701000206.

De Tocqueville, Alexis. 1835. De La Démocratie En Amérique. Paris. 
Demaria, Federico, Francois Schneider, Filka Sekulova, and Joan Martinez-Alier. 2013. "What Is Degrowth? From An Activist Slogan To A Social Movement". Environmental Values 22 (2): 191-215. doi:10.3197/096327113×13581561725194.

Department of Justice, Government of Canada. 2021. Rupert's Land and North-Western Territory - Enactment No. 3.

https://www.justice.gc.ca/eng/rp-pr/csj-sjc/constitution/lawreg-loireg/p1t31.html accessed 23 January 2021.

Devecka, Martin. 2015. "Raisins D’Etat: Trade, Politics, And Diplomacy In The History Of The Levant Company". Political Power And Social Theory, 77-94. doi:10.1108/s0198-871920150000029004.

Doyle, Don H. 1977. The Social Functions of Voluntary Associations in a NineteenthCentury American Town. 1 Soc. Sci. Hist. 333.

Duff, Patrick William. 1938. Personality in Roman Private Law. Cambridge: Cambridge University Press.

Dung, Nguyen Manh. 2017. "Activities of La Compagnie Française Des Indes Orientales in Siam in the Second Half of the 17th Century Revisited". Journal of Mekong Societies 13 (1), 1-18. https://so03.tci-thaijo.org/index.php/mekongjournal/article/view/84911.

Dunning, Chester. 1989. "James I, The Russia Company, And The Plan To Establish A Protectorate Over North Russia". Albion 21 (2): 206-226. doi:10.2307/4049926.

Eisenstein, Charles. 2011. Sacred Economics: Money, Gift, \& Society In The Age Of Transition. Berkeley, California: North Atlantic Books.

Ekama, Kate. 2012. "Slavery In Dutch Colombo: A Social History". Masters degree in History of European Expansion and Globalisation, Department of History Universiteit Leiden.

https://studenttheses.universiteitleiden.nl/access/item\%3A2631805/view

Epstein, Stephan R. 1998. "Craft Guilds, Apprenticeship, And Technological Change In Preindustrial Europe". The Journal Of Economic History 58 (3): 684-713. doi:10.1017/s0022050700021124.

Eroğlu, Muzaffer. 2008. "Limited Liability In Turkish Law". European Business Organization Law Review 9 (2): 237-265. doi:10.1017/s1566752908002371. 
Euler, Johannes, and Leslie Gauditz. 2017. "Commons Movements: Self-Organized (Re)Production As A Social-Ecological Transformation". In Degrowth In Bewegung(En) 32 Alternative Wege Zur Sozial-Ökologischen Transformation. Konzeptwerk Neue Ökonomie e. V. (Hrsg.), DFG-Kolleg Postwachstumsgesellschaften (Hrsg.).

Ėve, Prosper. 2010. "Les Indiens à Bourbon au temps de l'esclavage ou l'Histoire d'une dissonance" pp.35--66. In n S. Fuma \& S. Pannirselvame (dir.), Diaspora indienne dans l'histoire des îles et pays de l'océan Indien.

Feiner, Lauren. 2021. "States Bring A New Antitrust Suit Against Google Over Its Mobile App Store". CNBC, , 2021.

https://www.cnbc.com/2021/07/07/states-bring-new-antitrust-suit-against-google-over -google-play.html.

Feldman, Gerald and Nocken, Ulrich. 1975. Trade Associations and Economic Power: Interest Group Development in the German Iron and Steel and Machine Building Industries, 1900-1933. Business History Review, 49(4), pp.413-445.

Ferrero, Ignacio, W. Michael Hoffman, and Robert E. McNulty. 2014. "Must Milton Friedman Embrace Stakeholder Theory?". Business And Society Review 119 (1): 37-59. doi:10.1111/basr.12024.

Forsyth, Tim, and Craig Johnson. 2014. "Elinor Ostrom's Legacy: Governing The Commons And The Rational Choice Controversy". Development And Change 45 (5): 1093-1110. doi:10.1111/dech.12110.

Frankl, Jennifer L. 1999. "An Analysis Of Japanese Corporate Structure, 1915-1937". The Journal Of Economic History 59 (4): 997-1015. doi:10.1017/s0022050700024116.

Freedeman, Charles E. 1965. "Joint-Stock Business Organization In France, 1807-1867". Business History Review 39 (2): 184-204. doi:10.2307/3112696.

Freeman, R. Edward Edward, and John McVea. 2001. "A Stakeholder Approach To Strategic Management". SSRN Electronic Journal. doi:10.2139/ssrn.263511.

Gerschenkron, Alexander. 1962. Economic backwardness in historical perspective. Cambridge, MA: Harvard University Press. 
Gierke, Otto. 1900. Political Theories Of The Middle Age. Cambridge: Cambridge University Press.

Goetzmann, William N., and Elisabeth Koll. 2005. "The History Of Corporate Ownership In China: State Patronage, Company Legislation, And The Issue Of Control". In A History Of Corporate Governance Around The World: Family Business Groups To Professional Managers, 149-184. University of Chicago Press. http://www.nber.org/chapters/c10269.

González de Lara, Yadira. 2018. "Business Organization And Organizational Innovation In Late Medieval Italy" 65-87. In: H. Wells, ed., Research Handbook on the History of Corporate and Company Law. Edward Elgar Publishing.

Guinnane, Timothy W., 2018. "German Company Law 1794-1897". doi:10.4337/9781784717667.00015. In: H. Wells, ed., Research Handbook on the History of Corporate and Company Law. Edward Elgar Publishing.

Gunn, L. Ray.1988. The Decline of Authority: Public Economic Policy and Political Development in New York, 1800-1860. Ithaca: Cornell University Press.

Hall, Peter Dobkin. 1992. Inventing the Nonprofit Sector and Other Essays on Philanthropy, Voluntarism, and Nonprofit Organizations. Baltimore: The Johns Hopkins University Press.

Hansmann, Henry, Reinier Kraakman, and Richard Squire. 2006. "Law and the Rise of the Firm." Harvard Law Review 119, no. 5: 1333-403. Accessed: http://www.jstor.org/stable/4093574.

Hansmann, Henry. 1996. The Ownership of Enterprise. Cambridge: Harvard University Press.

Harris, Ron. 2000. Industrializing English Law: Entrepreneurship and Business Organization. Cambridge: Cambridge University Press.

Harris, Ron. 2018. "Trading with strangers: the corporate form in the move from municipal governance to overseas trade"pp.88-118. In: H. Wells, ed., Research Handbooks on the history of corporate and company law. Cheltenham: Edward Elgar Publishing Limited.

Harris, R., 2020. Going the distance: Eurasian Trade and the Rise of the Business Corporation, 1400-1700. Princeton University Press. 
Haudrère, Philippe. 1989. La Compagnie française des Indes au XVIIle siècle : 1719-1795. 4. Paris: Librairie de l'Inde.

Helfrich, Silke, Rainer Kuhlen, Wolfgang Sachs, and Christian Siefkes. 2010. "The Commons - Prosperity By Sharing". Berlin: Heinrich Böll Foundation. https://www.boell.de/sites/default/files/20101029_Commons_Prosperity_by_Sharing. pdf.

Honeyman, Ryan, and Tiffany Jana. 2019. The B Corp Handbook: How You Can Use Business As A Force For Good. 1st ed.

Howard, Stanley E. 1932. "Business Partnerships In France Before 1807". The Accounting Review 7 (4): 242-257.

Hutcheson, James Olan. 2007. "The End Of A 1,400-Year-Old Business". Bloomberg (online), 2007. Available at (Accessed 20 August 2020) :

https://www.bloomberg.com/news/articles/2007-04-16/the-end-of-a-1-400-year-old-b usinessbusinessweek-business-news-stock-market-and-financial-advice.

Isakson, Hans R., and Shauntreis Sproles. 2008. "A Brief History Of Native American Land Ownership". Indigenous Peoples And Real Estate Valuation, 63-75. doi:10.1007/978-0-387-77938-6_4.

Judd, Carol M. 2008. "Native Labour And Social Stratification In The Hudson's Bay Company's Northern Department 1770-1870". Canadian Review Of Sociology/Revue Canadienne De Sociologie 17 (4): 305-314. doi:10.1111/j.1755-618x.1980.tb00707.x.

Kallis, Giorgos, Vasilis Kostakis, Steffen Lange, Barbara Muraca, Susan Paulson, and Matthias Schmelzer. 2018. "Research On Degrowth". Annual Review Of Environment And Resources 43 (1): 291-316. doi:10.1146/annurev-environ-102017-025941.

Kaufman, Jason. 2008. "Corporate Law And The Sovereignty Of States". American Sociological Review 73 (3): 402-425. doi:10.1177/000312240807300303.

Kawano, Emily. 2018. "Solidarity Economy: Building An Economy For People \& Planet". Next System Project (The Democracy Collaborative). https://www.solidarityeconomy.coop/wp-content/uploads/2017/06/Kawano-E.-2018_S olidarity-Economy.pdf.

Kazıcı, Ziya. 1988. "Ahîlik". TDV İslam Ansiklopedisi (Cilt. 1, 540-542). https://islamansiklopedisi.org.tr/ahilik 
Kennedy, Paul. 1988. The Rise And Fall Of The Great Powers: Economic Change And Military Conflict From 1500 To 2000. 2nd ed. London: Unwin Hyman Limited.

Kim, Sung-Bae and Cho Sung Bong. 2015. "The Tragedy Of The Privatization Of The Commons". In Commons Amidst Complexity And Change, The Fifteenth Biennial Conference Of The International Association For The Study Of The Commons. Indiana University. http://hdl.handle.net/10535/9840.

Kirby, William C. 1995. China unincorporated: Company law and business enterprise in twentieth-century China. Journal of Asian Studies 54 (1): 43-63.

Klopfer, Peter H., and Joan Polemics. 1988. "Have Animals Rights?". Journal Of The Elisha Mitchell Scientific Society 104 (3): 99-107. Accessed August 15, 2021. http://www.jstor.org/stable/24333945.

Knaap, Gerrit. 1981. "Europeans, Mestizos And Slaves: The Population Of Colombo At The End Of The Seventeenth Century". Itinerario 5 (2): 84-101. doi:10.1017/s0165115300007178.

Köktaş, Altuğ Murat. 2016. "Osmanlı İmparatorluğu'nda Piyasa Dizenlemeleri: 1500-1700 İstanbul Kadı Sicillerinde Narh Uygulamaları (Market Regulations In Ottoman Empire: Officially Decreed Price (Narh) Implementations Between 1500-1700 In Kadi Registries Of Istanbul)". Niğde Üniversitesi Iktisadi Ve Idari Bilimler Fakültesi Dergisi 9 (2). Available at: https://dergipark.org.tr/tr/download/article-file/185222.

Kotsiris, Lambros E. 1988. "An Antitrust Case In Ancient Greek Law". International Lawyer 22 (2). https://scholar.smu.edu/til/vol22/iss2/7/.

Kraakman, Reiner R., Paul Davies, Henry Hansmann, Gerard Hertig, Klaus J. Hopt, Hideki Kanda and Edward B. Rock. 2004. The Anatomy of Corporate Law: A Comparative and Functional Approach. Oxford: Oxford University Press.

Kroef, Justus M. Van Der. 1948. "The Decline And Fall Of The Dutch East India Company". The Historian 10 (2): 118-134. doi:10.1111/j.1540-6563.1948.tb00452.x.

Küçükdağ, Yusuf. 2016. "Ahilik (Osmanlı Dönemi)". Ahilik Ansiklopedisi. 2. Baskı, Cilt I, 223- 227 Ankara: CTA. 
Kuhli, Milan. 2013. "Power And Law In Enlightened Absolutism - Carl Gottlieb

Svarez' Theoretical And Practical Approach". Rechtsgeschichte -Legal History 2013 (21): 16-30. doi:10.12946/rg21/016-030.

Kujala, Johanna, Hanna Lehtimäki, and Päivi Myllykangas. 2016. "Toward A Relational Stakeholder Theory: Attributes Of Value-Creating Stakeholder Relationships". Academy Of Management Proceedings 2016 (1): 13609. doi:10.5465/ambpp.2016.13609abstract.

Kuran, Timur. 2001. 'The Provision of Public Goods under Islamic Law: Origins, Impact, and Limitations of the Waqf System.' Law and Society Review, 35(4), 841-97.

Kuran, Timur. 2005. 'The Absence of the Corporation in Islamic Law: Origins and Persistence.' The American Journal of Comparative Law, 53, 785-834.

Kuran, Timur. 2010. “Ortadoğu'daki Ekonomik Azgelişmişliğin Kurumsal Kökenleri” Kayseri Ticaret Odası. Kayseri.

Kuran, Timur. 2011. The Long Divergence: How Islamic Law Held Back the Middle East. Princeton: Princeton University Press.

Lai, Chi-kong. 1992. The Qing state and Merchant enterprise: The China Merchants' Company, 1872-1902. In To achieve security and wealth: The Qing imperial state and the economy, 1644-1911, ed. Jane Kate Leonard and John R. Watt, 139-55. Ithaca, NY: Cornell University Press.

Lamoreaux, Naomi R. 2019. "The Problem Of Bigness: From Standard Oil To Google". Journal Of Economic Perspectives 33 (3): 94-117. doi:10.1257/jep.33.3.94.

Larson, Pier. 2000. "The route of the slave from Highland Madagascar to the Mascarenes: commercial organization, 1770-1820” p. 119-180. In I. Rakoto (dir.), La route des esclaves: système servile et traite dans l'est malgache, Paris, L'Harmattan.

Lawson, Philip., 2014. The East India Company: A History. Routledge.

Liesen, Andrea, Christian Dietsche, and Jana Gebauer. 2014. "Succesfull Non-Growing Companies". SSRN Electronic Journal. doi:10.2139/ssrn.2623920.

Lubimenko, Inna. 1933. "Les Relations Commerciales et Politiques de l'Angleterre avec la Russie Avant Pierre le Grand”. Librairie Ancienne Honoré Champion, Paris. 
Luppi, Barbara, Francesco Parisi, and Shruti Rajagopalan. 2012. "The Rise And Fall Of The Polluter-Pays Principle In Developing Countries". International Review Of Law And Economics 32 (1): 135-144. doi:10.1016/j.irle.2011.10.002.

Lyubimenko, Inna Ivanovna. 1933. Les Relations Commerciales Et Politiques De L'angleterre Avec La Russie Avant Pierre Le Grand. Paris: Librairie Ancienne Honoré Champion.

Malmendier, Ulrike. 2009. "Law And Finance "At The Origin"". Journal Of Economic Literature 47 (4): 1076-1108. doi:10.1257/jel.47.4.1076.

McSheffrey, Elizabeth. 2016. "The Hudson's Bay Company Punished After Releasing Toxins Into St. Lawrence River". Canada's National Observer, 2016.

https://www.nationalobserver.com/2016/12/14/news/bay-canadas-iconic-departmentstore-gets-punished-releasing-pcbs-major-river.

Mendels, Franklin F. 1972. "Proto-Industrialization: The First Phase Of The Industrialization Process". The Journal Of Economic History 32 (1): 241-261. doi:10.1017/s0022050700075495.

Meyer, Camille. 2020. "The Commons: A Model For Understanding Collective Action And Entrepreneurship In Communities". Journal Of Business Venturing 35 (5): 106034. doi:10.1016/j.jbusvent.2020.106034.

Miller, Ethan. 2004. "Solidarity Economics: Strategies For Building New Economies From The Bottom-Up And The Inside-Out". Socioeco. Org, Ripess Europe, Ripess International, Coredem. Available at:

http://www.socioeco.org/bdf_fiche-document-1201_fr.html

Muhammad, S., Long, X. and Salman, M., 2020. COVID-19 pandemic and environmental pollution: A blessing in disguise?. Science of The Total Environment, 728, p.138820.

Muijsenbergh, Winfried van den. 2002. "Corporate Governance: The Dutch Experience". Global Business \& Development Law Journal 16 (1): 63-73. https://scholarlycommons.pacific.edu/globe/vol16/iss1/6.

Needles Jr, Belverd E., Ahmet Turel, Evren Dilek Sengur, and Asli Turel. 2012. "Corporate Governance In Turkey: Issues And Practices Of High-Performance Companies". Accounting And Management Information Systems 11 (4): 510-531. 
Nicholas, Tom. 2015. "The Organization of Enterprise in Japan." The Journal of Economic History 75 (2). Cambridge University Press: 333-63. doi:10.1017/S0022050715000649.

Nies, Judith. 1996. Native American History. New York: Ballantine Books.

Noya, Antonella, and Emma Clarence. 2013. Policy Brief On Social Entrepreneurship. Paris: OECD. Available at: https://www.oecd.org/cfe/leed/Social\%20entrepreneurship\%20policy\%20brief\%20EN FINAL.pdf

Nugent, John H.,and Gilbert Werema. 2015. "Does Profit Maximization Impact Sustainability? - An Examination". SSRN Electronic Journal. doi:10.2139/ssrn.2637407.

Odabaşı, Zehra. 2008. Bir Ahi Dostu : Franz Taeschner Hayatı Ve Eserleri. Ankara: A. E. Ü. Ahilik Kültürünü Araştırma Merkezi.

OECD. 2008. "The Polluter Pays Principle: Definition, Analysis, Implementation". OECD Publishing, Paris, https://doi.org/10.1787/9789264044845-en.

Ogilvie, Sheilagh C., 2011. Institutions and European Trade: Merchant Guilds, 1000-1800. Cambridge: Cambridge University Press.

Ortaylı, İlber. 2010. Türkiye Teşkilât Ve Idare Tarihi. Ankara: Cedit Neşriyat.

Ostrom, Elinor. 1990. Governing The Commons - The Evolution Of Institutions For Collective Action. Cambridge University Press. Available at Internet Archive: archive.org/details/ElinorOstromGoverningTheCommons/page/n1/mode/2up.

Özesmi, Uygar. 2019. The Prosumer Economy -- Being Like A Forest. arXiv: General Economics.

Öztürk, Mustafa. 1991. "Osmanlı Dönemi Fiyat Politikası Ve Fiyatlarının Tahlili". Belleten 55 (212): 87-100.

https://dergipark.org.tr/en/pub/ttkbelleten/issue/62524/943950\#article_cite.

Palmater, Pamela. 2017. "Death By Poverty: The Lethal Impacts Of Colonialism". In Power And Resistance: Critical Thinking About Canadian Social Issues, 6th ed., 51-81. Halifax: Fernwood Publishing. 
Pamuk, Şevket. 1990. 100 Soruda Osmanlı - Türkiye Iktisadi Tarihi 1500-1914. İstanbul: Gerçek Yayınevi.

Papadopoulos, Anestis S. 2010. The International Dimension Of EU Competition Law And Policy. 1st ed. New York: Cambridge University Press.

Pearson, Ryan M., Michael Sievers, Eva C. McClure, Mischa P. Turschwell, and Rod M. Connolly. 2020. "COVID-19 Recovery Can Benefit Biodiversity". Science 368 (6493): 838.2-839. doi:10.1126/science.abc1430.

Pettigrew, William A., and David Chan Smith. 2017. A History Of Socially Responsible Business, C.1600--1950. doi:10.1007/978-3-319-60146-5

Poon, Daryl. 2011. "The Emergence And Development Of Social Enterprise Sectors". Social Impact Research Experience (SIRE).

https://repository.upenn.edu/sire/8.

Prakash, Om. 1985. The Dutch East India Company And The Economy Of Bengal, 1630-1720 - Princeton Legacy Library. Princeton: Princeton University Press.

Raben, Remco. 1996. Batavia And Colombo: The Ethnic And Spatial Order Of Two Colonial Cities, 1600-1800. Leiden University.

https://www.academia.edu/715645/Batavia_and_Colombo_The_Ethnic_and_Spatial _Order_of_Two_Colonial_Cities_1600_1800_Ph_D_thesis_Leiden_1996_?auto=do wnload

Roh, Tae Hyup. 2016. "The Sharing Economy: Business Cases Of Social Enterprises Using Collaborative Networks". Procedia Computer Science 91: 502-511. doi:10.1016/j.procs.2016.07.129.

Romar, Edward J. 2002. "Virtue Is Good Business: Confucianism As A Practical Business Ethic". Journal Of Business Ethics 38 (1/2): 119-31. http://www.jstor.org/stable/25074783.

Roulet, Thomas, and Joel Bothello. 2020. "Why "De-Growth" Shouldn'T Scare Businesses". Harvard Business Review, , 2020.

http://www.hbr.org/2020/02/why-de-growth-shouldnt-scare-businesses.

Ruskola, Teemu. 2018. "Corporation Law in Late Imperial China". Research Handbook on the History of Corporate and Company Law (Harwell Wells ed., Edward Elgar Press 2018), Emory Legal Studies Research Paper No. 18-444, Available at SSRN: https://ssrn.com/abstract=3140756 
Rutz, Christian, Matthias-Claudio Loretto, Amanda E. Bates, Sarah C. Davidson, Carlos M. Duarte, Walter Jetz, and Mark Johnson et al. 2020. "COVID-19 Lockdown Allows Researchers To Quantify The Effects Of Human Activity On Wildlife". Nature Ecology \& Evolution 4 (9): 1156-1159. doi:10.1038/s41559-020-1237-z.

Sawyer, Laura Phillips. 2019. "US Antitrust Law And Policy In Historical Perspective". Oxford Research Encyclopedia Of American History. doi:10.1093/acrefore/9780199329175.013.623.

Scott, William Robert.1912. The Constitution and Finance of English, Scottish and Irish Joint-Stock Companies to 1720. Cambridge: Cambridge University Press.

Segrestin, Blanche, Armand Hatchuel, and Kevin Levillain. 2020. "When The Law Distinguishes Between The Enterprise And The Corporation: The Case Of The New French Law On Corporate Purpose". Journal Of Business Ethics 171 (1): 1-13. doi:10.1007/s10551-020-04439-y.

Şensoy, Fatma. 2018. "Şirket-I Hayriye: Osmanlı Boğaziçi Taşımacılık Şirketi". Muhasebe Ve Finans Tarihi Araştırmaları Dergisi, 239-279. https://dergipark.org.tr/tr/pub/muftad/issue/38342/444253.

Shakespeare, Howard. 1997. "The Compagnie Des Indes". Journal Of The International Bond \& Share Society 20 (1): 34-37.

http://scripophily.org/wp-content/uploads/2016/03/Scripophily-Journal-1997-02-Febru ary-1997.pdf.

Shorto, Russell. 2013. Amsterdam: A History Of The World'S Most Liberal City. New York: Doubleday.

Şimşek, Muhittin. 2002. Ahilik: TKY Ve Tarihteki Bir Uygulaması Ahilik. İstanbul: Hayat.

Smiddy, Linda O., and Lawrence A. Cunningham. 2010. Corporations And Other Business Organizations. 7th ed. LexisNexis.

Svendsen, Gert Tinggard, and Yoshifumi Ueda. 2002. "How To Solve The Tragedy Of The Commons? Social Entrepreneurs And Global Public Goods". http://www.researchgate.net/publication/5093560 How to Solve the Tragedy of th e_Commons_-_Social_Entrepreneurs_and_Global_Public_Goods. 
Tapaninaho, Riikka, and Johanna Kujala. 2019. "Reviewing The Stakeholder Value Creation Literature: Towards A Sustainability Approach". World Sustainability Series, 3-36. doi:10.1007/978-3-030-03562-4_1.

The Guardian, 2020. Most political unrest has one big root cause: soaring inequality. [online] Available at:

https://www.theguardian.com/commentisfree/2020/jan/24/most-political-unrest-has-o ne-big-root-cause-soaring-inequality (Accessed 13 August 2020).

Thiébaut, Rafaël. 2017. "Traite Des Esclaves Et Commerce Néerlandais Et Français À Madagascar (Xviie Et Xviiie Siècles)". Ph.D, Université Paris 1 - Panthéon Sorbonne \& Vrije Universiteit Amsterdam.

Throckmorton, Arthur L. 1958. Oregon Historical Quarterly 59 (4): 341-44. http://www.jstor.org/stable/20612437.

Tu, Weiming. 2013. "Confucian Humanism In Perspective". Front. Lit. Stud. China 7 (3): 333-338. doi:10.3868/s010-002-013-0019-1.

Turkish Commercial Law 6102. 2011. Official Journal: Başbakanlık Mevzuatı Geliştirme ve Yayın Genel Müdürlüğü.

Turner, John D. 2018. "The Development Of English Company Law Before 1900". 121-141. doi:10.4337/9781784717667.00013. In: H. Wells, ed., Research Handbook on the History of Corporate and Company Law. Edward Elgar Publishing.

United Nations Department of Economic and Social Affairs. 2020. "Inequality In A Rapidly Changing World". World Social Report 2020. United Nations. https://www.un.org/sites/un2.un.org/files/1597340290.171.pdf.

United Nations. 2019. "The Sustainable Development Goals Report". New York. https://unstats.un.org/sdgs/report/2019/The-Sustainable-Development-Goals-Report2019.pdf.

Utting, Peter, Nadine Van Dijk, and Marie-Adélaïde Matheï. 2014. "Social And Solidarity Economy: Is There A New Economy In The Making?". UNRISD Occasional Paper: Potential And Limits Of Social And Solidarity Economy 10. https://www.econstor.eu/handle/10419/148793. 
Ventoruzzo, Marco, and Giulio Sandrelli. 2016. "Classes Of Shares And Voting Rights In The History Of Italian Corporate Law". SSRN Electronic Journal, 269-297. doi:10.2139/ssrn.2875724.

Vliet, Lars van. 2014. "The Netherlands - New Developments In Dutch Company Law: The "Flexible" Close Corporation". Journal Of Civil Law Studies 7 (1). https://digitalcommons.law.Isu.edu/jicls/vol7/iss $1 / 8$.

Von-Gierke, Otto Friedrich. 1900 [1881]. Political Theories of the Middle Age. Cambridge: Cambridge University Press.

Wallis, John Joseph. 2005. "Constitutions, Corporations, And Corruption: American States And Constitutional Change, 1842 To 1852". The Journal Of Economic History 65 (1): 211-256. doi:10.1017/s0022050705050084.

Wang, JiangYu. 2008. "An Overview Of China's Corporate Law Regime". SSRN Electronic Journal. doi:10.2139/ssrn.1222061.

Weber, Max. 2003 [1889]. The History of Commercial Partnerships. Translated and Introduced by Lutz Kaelber. Lanham, MD: Rowman \& Littlefield.

Wiener, Megan. 2020. "Antitrust Law Versus "Big Tech" Companies". California Legal Journal: Berkley Legal Studies Association, 18-31.

http://legalstudies.berkeley.edu/wp-content/uploads/2020/06/blsa-2020-1-2.pdf\#page $=24$.

Wood, Alfred C. 1935. A History Of The Levant Company. Frank Cass \& Co. Ltd.

Woodward, Susan. 1985. The Struggle for Fungibility of Joint-Stock Shares as Revealed in W. R. Scott's Constitution and Finance of English, Scottish, and Irish Joint-Stock Companies to 1720. UCLA Working Paper, no. 377.

Wright, Robert E. 2018. "For- And Non-Profit Special Corporations In America, 1608-1860" 480-509. doi:10.4337/9781784717667.00028. In: H. Wells, ed., Research Handbook on the History of Corporate and Company Law. Edward Elgar Publishing.

Yazıcı, Nesimi. 1996. "Lonca Sisteminin İşsizlik Sigortasıyla İlgisi Üzerine Bazı Düşünceler". Ankara Üniversitesi Illahiyat Fakültesi Dergisi 35 (1): 155-165. doi:10.1501/ilhfak_0000000853. 
Yoshimura, Norihisa, and Hidekazu Sone. 2006. "Observations Of Kongo Gumi's Corporate Creed: Research On The Corporate Creed Observed In The Living Company In Japan". The Annals Of The Economic Society, 143-152.

https://core.ac.uk/reader/198553110.

Yüksel, Ayşe Nurefşan, and Aykut Göksel. 2020. "Bölgesel Kümelenme Örneği Olarak Ahilik Teşkilatı". Ahi Evran Üniversitesi Sosyal Bilimler Enstitüsü Dergisi 6 (3): 794-812. doi:10.31592/aeusbed.700672.

Zambrano-Monserrate, Manuel A., María Alejandra Ruano, and Luis Sanchez-Alcalde. 2020. "Indirect Effects Of COVID-19 On The Environment". Science Of The Total Environment 728. doi:10.1016/j.scitotenv.2020.138813.

Zencirci, Gizem. 2015. "From Property to Civil Society: The Historical Transformation of Vakifs in Modern Turkey (1923-2013)". International Journal Of Middle East Studies 47 (3): 533-554. doi:10.1017/s0020743815000537.

Zheliazkov, Georgi, and Konstantin Stoyanov. 2015. "The Social Enterprise As An Alternative Economic Model For Small And Medium-Sized Enterprises. Examples Of Successful Social Enterprises". Trakia Journal Of Sciences 13 (Suppl.1): 274-277. doi:10.15547/tjs.2015.s.01.046. 